\title{
Ammonium Ocean following the end-Permian Mass Extinction
}

2

3

$4{ }^{1}$ GeoZentrum Nordbayern, Universität Erlangen-Nürnberg, Schlossgarten 5, 91054

5 Erlangen, Germany

$6 \quad{ }^{2}$ School of Environmental Sciences, University of Hull, Hull, HU6 7RX, United Kingdom

$7 \quad{ }^{3}$ School of Earth and Environment, University of Leeds, Leeds LS2 9JT, UK

$8 \quad{ }^{4}$ State Key Laboratory of Biogeology and Environmental Geology, China University of

9 Geosciences (Wuhan), Wuhan 430074, P.R. China

10

11

12 *corresponding author: E-mail: yadong.sun@fau.de (Y.D. Sun) 
14 Abstract: The aftermath of end-Permian mass extinction was marked by a $\sim 5$ million year interval of poorly-understood, extreme environments that likely hindered biotic recovery. Contemporary nitrogen isotope variations are considered, using a new conceptual model, to support a scenario that shows intensive nitrate-removal processes gradually depleted the global oceanic nitrate inventory during long-lasting oceanic anoxia. Enhanced nitrogen fixation shifted the oceanic nitrogenous nutrient (nutrient-N) inventory to an ammoniumdominated state. Ammonium is toxic to animals and higher plants but fertilizes algae and bacteria. This change in ocean chemistry could account for the intense and unexplained losses of nektonic taxa and the proliferation of microbial blooms in the Early Triassic. The transition from a nitrate ocean to an ammonium ocean was accompanied by a decrease in respiration efficiency of organisms and a shrinking oceanic nutrient- $\mathrm{N}$ inventory, ultimately leading to generally low productivity in the Early Triassic oceans. These unappreciated nutrient changes during episodes of prolonged ocean anoxia may be the key life-limiting factor at such times. 


\section{Introduction}

Following the most devastating extinction of the Phanerozoic, the Early Triassic ( 253-247 Ma) interval is considered to have been an extreme hothouse world (Kidder and

Worsley, 2010; Winguth et al., 2015) with equatorial sea-surface temperatures (SSTs) consistently higher than $32{ }^{\circ} \mathrm{C}$ (Sun et al., 2012). Such temperature extremes reduce the solubility of all gases in the ocean, decrease photosynthetic efficiency in terrestrial plants and phytoplankton and increase metabolic energy demands (approximately double the cost for every $10^{\circ} \mathrm{C}$ rise according to the $Q_{10}$ temperature coefficient), and can lead to intense oceanic anoxia, low biodiversity, and animals with small body sizes (Wignall and Twitchett, 2002; Twitchett, 2007; Bottjer et al., 2008). The peak of the hothouse occurred during the Smithian-Spathian (S-S) transition, 2 million years after the end-Permian mass extinction, when equatorial SSTs reached $\sim 40{ }^{\circ} \mathrm{C}$ (Sun et al., 2012) during a major $\sim 6-8 \%$ negative carbon isotope excursion (Payne et al., 2004; Sun et al., 2015). Many nektonic taxa that were well adapted to the harsh post-extinction environments finally succumbed at the S-S transition, suffering even greater proportional losses than at the end of the Permian (Stanley, 2009).

The warm climate and concomitant increased weathering and continental runoff in the Early Triassic enhanced nutrient delivery to the oceans (Algeo et al., 2011), theoretically elevating primary productivity and amplifying oxygen deficiency in the water column (Kump et al., 2005), ultimately producing euxinia with noxious $\mathrm{H}_{2} \mathrm{~S}$. Such conditions exist today as localized "dead zones" like those found in the Gulf of Mexico (Rabalais et al., 2002), and they are an oft-cited mechanism for the end-Permian marine extinction and the delayed Early Triassic recovery (Kump et al., 2005; Algeo et al., 2011). All versions of the death-by-anoxia 
54 (euxinia) scenario assume that phosphorus (P) was the key bio-essential element that controlled productivity levels (Meyer et al., 2008). Cyanobacterial biomarker spikes and the development of microbialites during and in the immediate aftermath of the end-Permian crisis (Pruss et al., 2006; Xie et al., 2010) potentially reflect this high productivity scenario.

In addition to $\mathrm{P}$, the other productivity-limiting nutrient in the ocean is N. Unlike $\mathrm{P}$, nutrient- $\mathrm{N}$ availability is not a function of terrestrial input since the oceanic $\mathrm{N}$ cycle is largely internal and biologically-driven (Sigman et al., 2009) (Fig. 1). Under anoxic conditions denitrification is enhanced and removes nitrate (including nitrite) as $\mathrm{N}_{2}$ while $\mathrm{P}$ is released from sediments (Van Cappellen and Ingall, 1994). This process, if widespread and maintained for a prolonged time, generates a nitrate-poor but P-rich ocean (Grasby et al., 2012; Grasby et al., 2016). The Early Triassic is known for global absence of phosphorites and other P-rich sedimentary rocks, suggesting intensive P-recycling into seawater at this time. Although P can be additionally and partially scavenged by Fe minerals (Feely et al., 1991), Fe shuttles in the Early Triassic oceans were dominated by pyrite burial, and quantitatively not comparable to banded iron formation deposition in the Archean and Paleoproterozoic oceans. Thus, P scavenged by Fe minerals is unlikely to have balanced the excess $\mathrm{P}$ input by weathering. Nitrogen could have become the bio-limiting nutrient in the euphotic zone since marine phytoplankton requires 14-16 times more $\mathrm{N}$ than $\mathrm{P}$ (i.e., the Redfield Ratio). The high SSTs of the Early Triassic (Sun et al., 2012) likely deepened the thermocline, lowered the pole-to-equator temperature gradient and weakened ocean circulation (Winguth et al., 2015). Under such circumstances, $\mathrm{PO}_{4}{ }^{3-}$ and $\mathrm{NO}_{3}{ }^{-}$were probably trapped beneath density barriers, inhibiting nutrient supply to the euphotic zone (Fig. 2C; Grasby et al., 2016; Penn et al., 2018). 
To understand the interplay of stratification intensity and the availability of different

nutrients in the Early Triassic oceans, we investigated nitrogen isotope $\left(\delta^{15} \mathrm{~N}\right)$ trends and trace metal concentrations during the Late Permian to Early Triassic in palaeo-equatorial Tethys (Xiakou and Jiarong sections, South China) and the Boreal Ocean (Vindodden section, Spitsbergen) (Fig. 2). The results, combined with our new conceptual model (Fig. 1), suggest the establishment of an "Ammonium Ocean" had severe consequences for the marine biosphere in the Early Triassic.

\section{Settings}

The South China Block was situated at an equatorial position in the eastern Tethys Ocean in the Early Triassic (Fig. 2A). Palaeogeographically, the study section at Xiakou was situated on the northern margin of the central Yangtze Platform. The study section at Jiarong was situated in the centre of the Nanpanjiang Basin, which was a V-shaped, deep water epicontinental basin that opened south-eastward to the Panthalassa Ocean (Lehrmann et al., 2003).

The Xiakou section (GPS: $31^{\circ} 6^{\prime} 55.82^{\prime \prime N}, 110^{\circ} 48^{\prime} 15.87^{\prime E}$ ) is located in Xingshan County, $400 \mathrm{~km} \mathrm{NW}$ of Wuhan. The continuous sequence, from late Changhsingian to Spathian, crops out alongside a local road. The late Changhsingian strata are characterized by dark grey to black, marly carbonate and marls. The lithology is replaced upsection by thinly bedded grey carbonate and shales of the Daye Formation.

The Jiarong section (GPS: $25^{\circ} 55^{\prime} 17^{\prime \prime} \mathrm{N}, 106^{\circ} 33^{\prime} 50^{\prime \prime} \mathrm{E}$ ) is located in Huishui County, $\sim 85 \mathrm{~km}$ south of Guiyang City in the Guizhou Province. The Smithian-Spathian succession is composed of a middle-late Smithian carbonate unit, a latest Smithian black shale unit and an 
121

early Spathian reddish carbonate unit, representing a transition from a basinal setting to a shallower water environment across the S-S boundary interval (Chen et al., 2015; Sun et al., 2015). Sediments in the upper part of the Carbonate Unit and the Black Shale Unit are finely laminated and lack bioturbation. Fossils are generally rare, except for conodonts. Small ammonoids and scaphopods occur in the Spathian Griotte Unit (Sun et al., 2015).

During the Permo-Triassic the Svalbard Archipelago was situated on the epicontinental shelf of the northern passive margin of Pangaea adjacent to the Boreal Ocean in high temperate latitudes ( 55 to $60^{\circ} \mathrm{N}$ ) (Hounslow et al., 2008). The S-S strata of central Spitsbergen belong to the Vikinghøgda Formation, and are best documented from the Vindodden section (Mørk et al., 1999; Wignall et al., 2016).

The Vindodden section (GPS: $78^{\circ} 19^{\prime} 39^{\prime \prime} \mathrm{N}, 16^{\circ} 30^{\prime} 19^{\prime \prime} \mathrm{E}$ ) lies in the lower slopes of Botneheia Mountain, south of Sassenfjorden, a north-eastern arm of Isfjorden. The S-S sequence consists mainly of a lower unit of dark clay/siltstone unit of Smithian age and an upper siltstone-sandstone unit of Spathian age. The transition from the Smithian to the Spathian is marked by a laminated thin dolostone ledge of earliest Spathian age. The phosphatic black clay/shales atop the Vikinghødga Formation characterise the Middle Triassic Botneheia Formation (Wignall et al., 2016). Fossils are rare in the study section, except for a few Posidonia bivalves, Planolites trace fossils and ammonoids. Though very low in abundance, conodonts occur throughout the section, providing biostratigraphic constraints.

\section{Conceptual Model}


Our conceptual model for the oceanic nitrogen cycle consists of four end-members. They are $\mathrm{N}_{2}$, the $\mathrm{NH}_{4}{ }^{+} / \mathrm{NH}_{3}$ pair, the $\mathrm{NO}_{2}-\mathrm{NO}_{3}{ }^{-}$pair and organic-bonded nitrogen. Amongst these, $\mathrm{NH}_{4}{ }^{+} / \mathrm{NH}_{3}$ and $\mathrm{NO}_{2}-/ \mathrm{NO}_{3}{ }^{-}$are the main forms of dissolved inorganic nutrient- $\mathrm{N}$ in the ocean. The four end-members are linked by eight known reactions in the nitrogen cycle (Fig. 1). These reactions are further subdivided into aerobic reactions (e.g., nitrification), anaerobic reactions (e.g., denitrification) and non-redox sensitive reactions (e.g., nitrogen fixation). This subdivision leads to three simplified sub-models for oceanic nitrogen cycle in fully oxic (Fig. 1 model A), fully anoxic (Fig. 1 model B) and fully euxinic conditions (Fig. 1 model C). In modern ocean settings, the oceanic nitrogen cycle is dominated by processes summarized in the model $\mathrm{A}$, while model $\mathrm{B}$ describes the nitrogen cycle in the oxygen minimum zone (OMZ). In warm, stratified and oxygen-depleted Early Triassic oceans, the models B and C describes the main oceanic nitrogen cycle with the model A only applicable to the thin, oxygenated surface layer. Though nitrification is an aerobic reaction, it can occur at very low oxygen concentrations at a lower rate (Bristow et al., 2016). In such cases, the dissolved nutrient-N inventory is in a subtle balance between nitrate net production and net consumption, depending on the intensity of ocean anoxia. For example, at the Black Sea thermocline, anaerobic ammonium oxidation (anammox) bacteria outcompete aerobic nitrifying bacteria for nitrite (Lam et al., 2007), leading to nitrate and nitrite net consumption.

Nitrate production by nitrification is mainly carried out by ammonia-oxidizing bacteria $(\mathrm{AOB})$ and ammonia-oxidizing archaea $(\mathrm{AOA})$. This process is generally considered to be light-sensitive for two reasons: 1) some AOB show photoinhibition (e.g., Guerrero and Jones, 1996), and 2) AOA, though more abundant than AOB in the euphotic zone and not 
145 light-inhibited per se, are often outcompeted by phytoplankton for $\mathrm{NH}_{4}{ }^{+}$. The rate of

146

147

148

149

150

151

152

153

154

155

156

157

158

159

160

161

162

163

164

165

166

167

nitrification of AOA is lower in the euphotic zone during the day and in the summer due to limited $\mathrm{NH}_{4}{ }^{+}$supply while the highest rate occurs at night and in the winter when competition with phytoplankton is lowest (Smith et al., 2014). Because the euphotic zone is only a thin layer of water column, the overall rates and efficiency of nitrification in the ocean depend critically on general redox conditions below the euphotic zone (e.g., Quan and Falkowski, 2009).

Denitrification has a high energy yield (Table 1) and the resupply of nitrate by nitrification is greatly inhibited in anoxic conditions. Thus, quantitatively nitrate must be in net consumption in intensive anoxic and euxinic oceans because nitrate produced by nitrification in the thin, oxygenated surface water column cannot compensate for the nitrate consumed by denitrification and anammox in anoxic and much thicker deeper water columns (Fig. 2C). Note that anaerobic ammonium oxidation by manganese oxides occurs in sediments rather than the water column (e.g., Hulth et al., 1999) and is excluded here.

We use the notion "ammonium ocean" to describe an oceanic state in which $\mathrm{NO}_{2}-$ and $\mathrm{NO}_{3}{ }^{-}$are largely depleted while $\mathrm{NH}_{4}{ }^{+}$is the main form of dissolved nutrient- $\mathrm{N}$. Note that dominance is not necessarily equal to high concentrations. Thus the term "ammonium ocean" does not necessarily imply globally high $\mathrm{NH}_{4}{ }^{+}$concentrations in the ocean (see 5.3 for further discussion on the heterogeneity of Early Triassic oceans).

\section{Methods (isotope and $\mathrm{C} / \mathrm{N}$ ratio analyses)}

For measurements of $\delta^{13} \mathrm{Corg}, \delta^{15} \mathrm{~N}$, and $\mathrm{C} / \mathrm{N}$ atomic ratios, weathered surfaces were cut off the samples. The trimmed samples were washed with distilled water, dried with 
compressed air and then milled to fine powder. On average $\sim 3$ to $\sim 5 \mathrm{~g}$ powders were immediately treated with $\sim 150 \mathrm{ml} 10 \% \mathrm{HCl}$ on a hotplate at $\sim 60{ }^{\circ} \mathrm{C}$ to dissolve any carbonate. The samples were stirred while slowly adding acid. The decarbonatization process was generally completed after 48 hours with the complete removal of dolomite and siderite phases. If not, acid was refreshed and the samples were treated further for 24-48 hours. Insoluble residues were washed repeatedly with deionized water until $\mathrm{pH} \approx 6$, dried in an oven at $60^{\circ} \mathrm{C}$, homogenized using a mortar and stored in small glass containers.

The $\delta^{13} \mathrm{Corg}$ and bulk rock $\delta^{15} \mathrm{~N}$ analyses were performed with a Flash EA 2000 elemental analyser connected online to ThermoFinnigan Delta V Plus mass spectrometer. All isotope values are reported in the conventional $\delta$-notation in per mille $(\%)$ relative to atmospheric air for $\delta^{15} \mathrm{~N}$ and to V-PDB for $\delta^{13} \mathrm{Corg}$. Reproducibility of measurements was monitored by replicate analyses of laboratory standards (synthetic urea) calibrated to international standards USGS $40\left(\delta^{13} \mathrm{C}=-26.39 \% ; \delta^{15} \mathrm{~N}=-4.52 \% 0\right)$ and USGS $41\left(\delta^{13} \mathrm{C}=\right.$ $\left.37.63 \% 0 ; \delta^{15} \mathrm{~N}=47.57 \% 0\right)$. The reproducibility was $\pm 0.08 \% 0(2 \sigma)$ for $\delta^{13} \mathrm{C}_{\mathrm{org}}, \pm 0.07 \%(2 \sigma)$ for total organic carbon (TOC), $\pm 0.14 \%(2 \sigma)$ for $\delta^{15} \mathrm{~N}$ and $\pm 0.20 \%(2 \sigma)$ for total nitrogen (TN). The repeatability of samples for $\delta^{15} \mathrm{~N}$ ranges from 0.05 to $0.18 \% 0(2 \sigma)$, with a single case of $0.42 \%$. Note that our $\delta^{15} \mathrm{~N}$ data, as in many other studies in this interval, represent a $\delta^{15} \mathrm{~N}_{\text {acidified }}$ (rather than $\delta^{15} \mathrm{~N}_{\text {bulk }}$ ) record in a strict sense. The $\mathrm{C} / \mathrm{N}_{\text {atomic }}$ ratio was calculated from (TOC/atomic weight of $\mathrm{C}) /(\mathrm{TN} /$ atomic weight of $\mathrm{N})$. The $\mathrm{TN}$ and TOC values are positively correlated $\left(\mathrm{r}^{2}=0.42,0.68\right.$ and 0.93 for Jiarong, Vindodden and Xiakou sections, respectively), suggesting organic matter was the primary source of $N$ (Fig. 3). Other sources include clay-bound $\mathrm{N}$ resulting from diagenetic $\mathrm{NH}_{4}{ }^{+}$release. The occurrence of clay-bound $\mathrm{N}$ may homogenise, but not necessarily perturb, $\delta^{15} \mathrm{~N}$. 
For $\delta^{13} \mathrm{C}_{\text {carb }}$ analyses, carbonate powders, preferably from micrites, were drilled on fresh-cut rock surfaces. The powders were reacted with $100 \%$ phosphoric acid at $70{ }^{\circ} \mathrm{C}$ in a Gasbench II connected online with a ThermoFinnigan Delta V Plus mass spectrometer. All values are reported in per mille relative to V-PDB by assigning $\delta^{13} \mathrm{C}$ values of $+1.95 \%$ to NBS19 and $-47.3 \%$ to IAEA-CO 9 and $\delta^{18} 0$ values of $-2.20 \%$ to NBS19 and $-23.2 \%$ to NBS18. Reproducibility was monitored by replicate analysis of laboratory standards calibrated to NBS 19 and NBS18, and was $\pm 0.04 \%$ for $\delta^{13} \mathrm{C}_{\text {carb }}$ and $\pm 0.04 \%$ for $\delta^{18} \mathrm{O}_{\text {carb }}(2 \sigma$; $n=20)$.

\section{Perturbations in global carbon and nitrogen cycles in the Early Triassic}

The $\delta^{13} \mathrm{C}_{\text {carb }}$ values of the Xiakou section show an increase from 1.22 to $2.16 \%$ in the late Changhsingian. This positive trend is followed by a negative excursion of $-2.8 \%$ across the Permian-Triassic (P-T) boundary (at $0 \mathrm{~m}$ height). A second, -2.0 \%o negative excursion occurs in the mid-late Griesbachian. The largest negative excursion of -3.0 \%o amplitude occurs in the Smithian. ${ }^{13} \mathrm{C}_{\text {carb }}$ values decrease from 2.04 to $-1.00 \%$ and remain low in the late Smithian (Fig. 4).

The $\delta^{13} \mathrm{C}$ org values of Jiarong and Vindodden sections show a similar pattern in the S$\mathrm{S}$ transition, but differ in absolute values by $\sim 1 \% 0 . \delta^{13} \mathrm{C}_{\mathrm{org}}$ from Jiarong shows a positive excursion of $\sim 5.5 \%$ from $-31.5 \%$ in the late Smithian to $-26.0 \%$ in the earliest Spathian. A slightly smaller positive excursion of $\sim 4.5 \%$ is registered at Vindodden, with values increasing from -32.5 to $-28.0 \%$ across the S-S boundary (at 56 m height; Fig. 4).

The $\delta^{13} \mathrm{C}_{\text {carb }}$ and $\delta^{13} \mathrm{Corg}$ variations from our study sections are consistent with published $\delta^{13} \mathrm{C}$ records (Payne et al., 2004; Grasby et al., 2012), and are therefore considered 
214 to record the global signature. The difference in absolute $\delta^{13} \mathrm{C}$ org values between Jiarong and 215 Vindodden is attributed to different primary producers between the equatorial and Boreal 216 oceans, which were likely to show different carbon isotopic fractionation during 217 photosynthesis. The $\delta^{13} \mathrm{C}$ perturbations, redox and sedimentary changes support a scenario 218 that intense oceanic anoxia in the late Smithian contributed to enhanced burials of organic carbon (i.e., black shale deposition and positive $\delta^{13} \mathrm{C}$ excursion) (Sun et al., 2015). reached a $\sim 3 \%$ peak immediately above the P-T boundary (Fig. 4). This was followed by a protracted, gradual decrease from the early Griesbachian to values of $\sim 0.5 \%$ in the late Smithian. At Jiarong, $\delta^{15} \mathrm{~N}$ values match those at Xiakou and then decrease to $\sim-1 \%$ across the S-S boundary (at $24.3 \mathrm{~m}$ height); a level that sees the onset of black shale deposition. A comparable trend across the S-S transition is seen at Vindodden although the $\delta^{15} \mathrm{~N}$ curve is offset in absolute value by $\sim 1 \%$ compared with the other sections (Fig. 4). The $\mathrm{C} / \mathrm{N}_{\text {atomic }}$ ratio (a measure of organic matter stoichiometry) generally co-varies with, but is opposite to, the observed trends in $\delta^{15} \mathrm{~N}$. Thus, $\mathrm{C} / \mathrm{N}_{\text {atomic }}$ at Xiakou decreases sharply across the P-T boundary from $>20$ to $\sim 2$, followed by a mild recovery to $\sim 10$ in the Dienerian and oscillations around $\sim 6$ in the Smithian. $\mathrm{C} / \mathrm{N}_{\text {atomic }}$ at Jiarong increases steadily from $\sim 10$ to $231 \sim 30$ towards the S-S boundary, followed by a decrease above its maxima of $\sim 40$ in the 232 earliest Spathian. At Vindodden, $\mathrm{C} / \mathrm{N}_{\text {atomic }}$ increases from $\sim 11$ to $\sim 20$ towards the $\mathrm{S}$-S boundary (at $56 \mathrm{~m}$ height) before decreasing to $\sim 15$ in the early Spathian.

The $\delta^{15} \mathrm{~N}$ data show minor regional variations compared to published records, with differences occurring mainly in the Late Permian (Fig. 5). Water column denitrification 236 occurred near the P-T boundary at Xiakou whereas in Arctic Canada and western Alberta 
denitrification prevailed in the latest Permian. The $\delta^{15} \mathrm{~N}$ shifts seen in the Early Triassic at Xiakou and Jiarong are comparable to reported patterns from the Sverdrup Basin (Knies et al., 2013; Grasby et al., 2016) and the western margin of Pangaea (Schoepfer et al., 2012). Since South China, the Sverdrup Basin and western Alberta were situated in very different climatic and oceanographic settings, and yet were connected to the Panthalassa ocean, we interpret their comparable $\delta^{15} \mathrm{~N}$ variations in the Early Triassic to reflect the global ocean signatures (Fig. 5). The divergence in $\delta^{15} \mathrm{~N}$ between Vindodden and other regions probably reflects a minor nitrate input from a polar current to Spitsbergen as well as its slightly more restricted environment (Fig. 2A).

\section{Discussion}

\subsection{Influence of diagenesis on $\delta^{15} \mathrm{~N}$ and $\mathrm{C} / \mathrm{N}$ atomic ratio}

Diagenesis can potentially alter both sedimentary $\delta^{15} \mathrm{~N}$ and the $\mathrm{C} / \mathrm{N}_{\text {atomic }}$ ratio. For example, degradation of amino acid during early diagenesis releases $\mathrm{NH}_{4}+$ to pore water. If the $\mathrm{NH}_{4}{ }^{+}$is absorbed by clay minerals, then sedimentary $\delta^{15} \mathrm{~N}$ would show minor changes compared to the original signature. Positive intercepts on the TN axis in our TN-TOC cross plot (Fig. 3) indicate the presence of excess clay-bound nitrogen in our samples. We consider our $\delta^{15} \mathrm{~N}$ to be a faithful record because data measured from adjacent carbonate and marl (shale) samples, although with large variations in TOC and clay content, show consistent values in $\delta^{15} \mathrm{~N}$ (Table 2) and our sections are from different sedimentary basins and underwent different diagenetic and burial history, and yet the $\delta^{15} \mathrm{~N}$ records are largely comparable with each other and published records. Only, the onset and duration of P-T water column denitrification show regional variations (Fig. 5). On the other hand, diagenesis can 
significantly alter the $\mathrm{C} / \mathrm{N}_{\text {atomic }}$ ratio, especially in TOC-poor, clay-rich sediments, and cause divergence from the Redfield Ratio to higher values. Diagenetic sulphate reduction, which removes $\mathrm{C}$ but not $\mathrm{N}$, can lower $\mathrm{C} / \mathrm{N}$ atomic ratio.

\subsection{Intensified denitrification, low sulphate concentration and a nitrate starved ocean}

The oceanic N cycle is largely microbially mediated (Altabet, 2006). The onset of intense and widespread anoxia in the latest Permian saw a profound change in dominance amongst oceanic microbial communities from aerobic to anaerobic respiration. Since the energy yield from denitrification $\left(\Delta \mathrm{G}^{0}=-445 \mathrm{~kJ} / \mathrm{mol} \mathrm{C}\right)^{1}$ is almost as efficient as that of aerobic respiration $\left(\Delta \mathrm{G}^{0}=-478 \mathrm{~kJ} / \mathrm{mol} \mathrm{C}\right)$, nitrate is the first energy source to be consumed in anoxic environments (Table 1). Thus, the shift to microbial anaerobic respiration is manifest as the positive $\delta^{15} \mathrm{~N}$ trend seen in the late Changhsingian at Xiakou and elsewhere (Fig. 5). This indicates widespread water column denitrification, and coincides with the onset of intensive anoxia (e.g., Grasby et al., 2012; Elrick et al., 2017).

Despite some regional variations, $\delta^{15} \mathrm{~N}$ records from different settings all indicate strong denitrification occurring across the P-T boundary, followed by a dominance of nitrogen fixation in the Early Triassic (Fig. 5). The $\delta^{15} \mathrm{~N}$ values in the Early Triassic of our study sections are depleted in ${ }^{15} \mathrm{~N}$ compared to the average $\delta^{15} \mathrm{~N}$ of modern oceans $(\sim 5$ \%o)(Altabet, 2007). Nitrate was likely depleted and nitrogen fixation dominated in both northern Boreal and equatorial Tethyan waters at this time. Reducing conditions amplify anaerobic reactions such as denitrification and anammox; reactions that selectively consume

\footnotetext{
${ }^{1} \Delta \mathrm{G}^{0}$ represents the standard Gibbs free energy of formation, a thermodynamic measure of energy absorption or yield of a reaction at the standard conditions $\left(25^{\circ} \mathrm{C}\right.$ and $\left.100 \mathrm{kPa}\right)$. Positive values suggest a reaction absorbs energy while negative values suggest a reaction yield energy. The more negative the values, the more energy is yielded though the reaction.
} 
nitrate depleted in ${ }^{15} \mathrm{~N}\left(\varepsilon=5-30 \%\right.$ ) and produce non-nutritious $\mathrm{N}_{2}$. As nitrate consumption continues, ${ }^{15} \mathrm{~N}$ becomes enriched in seawater, resulting in heavy $\delta^{15} \mathrm{~N}$ values in sedimentary organic matter (e.g. $\delta^{15} \mathrm{~N}>5 \%$ ). In modern oceans, intensive denitrification occurs in the oxygen minimum zone where organic matter and nitrate are both replete (Fig. 2C). In the Early Triassic anoxic oceans, denitrification and anammox probably occurred over a broad range of depths and theoretically would have generated high sedimentary $\delta^{15} \mathrm{~N}$ values (e.g. $\delta^{15} \mathrm{~N}=\sim 5-15 \%$ ). Instead, $\delta^{15} \mathrm{~N}$ values from both equatorial and boreal settings are in the 1 to $2 \%$ range. This can be explained through a nitrate-starved scenario in which the isotopic fractionation effect of denitrification and anammox decreases due to very low nitrate availability (i.e., exceptionally high denitrification rate) and intense seawater stratification while nitrogen fixation is the only source of nutrient-N. Alternatively, low $\delta^{15} \mathrm{~N}$ could suggest nitrate levels become so low that the heavy $\delta^{15} \mathrm{~N}$ of the residual nitrate can no longer dominate the isotopic composition of biomass. As the thermocline deepened during the Early Triassic hothouse, nitrate supply from deep-water environments to the euphotic zone had to overcome the density barrier, and this could only be achieved by diffusion (Fig. 2C). Diffusion would eventually have drained the nitrate inventory of deep-water reservoirs. In open water settings, nitrate consumption exceeding nitrate production was probably a protracted process, controlled by the evolution and intensity of ocean anoxia. This is consistent with the observed prolonged and gradual $\delta^{15} \mathrm{~N}$ decrease from the earliest Triassic to the S-S boundary (Grasby et al., 2016). Localized depletion of nitrate on some isolated platforms, marked by $\delta^{15} \mathrm{~N}$ falling to $\sim 0 \%$, occurred much earlier at the P-T boundary (Fig. 5); this was probably due to a lack of nitrate resupply from the deep reservoirs in such settings. 
The near-antithetic relationship between $\delta^{15} \mathrm{~N}$ and the $\mathrm{C} / \mathrm{N}_{\text {atomic }}$ ratio at the $\mathrm{S}-\mathrm{S}$ transition suggests that a common cause simultaneously drove $\delta^{15} \mathrm{~N}$ to lower values and the $\mathrm{C} / \mathrm{N}_{\text {atomic }}$ ratio to higher values (and vice versa). This is unlikely to be due to the input of terrestrial organic matter (which typically has low $\delta^{15} \mathrm{~N}$ and high $\mathrm{C} / \mathrm{N}_{\text {atomic }}$ ratios) because, with the near-extinction of land plants at the end of the Permian and the subsequent low terrestrial biomass on Pangea (Looy et al., 1999), terrestrial $\mathrm{N}$ input is unlikely to have affected the isotopic composition of the oceanic $\mathrm{N}$ pool. Instead, the factor that drove the $\delta^{15} \mathrm{~N}$ and $\mathrm{C} / \mathrm{N}_{\text {atomic }}$ ratio in opposite directions was probably the bioavailability of nitrate. In the case of low nitrate availability and long-term anoxia, nitrate-removal processes utilize nitrate and the corresponding isotopic fractionation effects decrease while nitrogen fixation is enhanced thereby compensating for the nutrient-N loss. Both processes lower $\delta^{15} \mathrm{~N}$ values of organic N. At the same time, anoxia enhances bacterial recycling of N-rich amino acids from organic matter (Van Mooy et al., 2002), leading to a more intense loss of sedimentary $\mathrm{N}$ during diagenesis and higher $\mathrm{C} / \mathrm{N}_{\text {atomic }}$ ratios.

Low sulphate concentrations and episodic euphotic zone euxinia characterize the Early Triassic oceans (Grice et al., 2005; Song et al., 2014). These are largely, or at least partially, due to enhanced bacterial sulphate reduction, perhaps due to high marine productivity (Schobben et al., 2015). However, with increasing water column $\mathrm{O}_{2}$ deficiency, heterotrophic bacteria favour energy extraction pathways with high yields. Sulphate reduction ranks low in this respect amongst anaerobic respiration (Table 1) and is only favoured once nitrate is depleted (Altabet, 2006). We thus argue that enhanced sulphate reduction in the Early Triassic oceans was probably a response to a functional shift in microbial communities from nitrate consuming $\left(\Delta \mathrm{G}^{0}=-445 \mathrm{~kJ} / \mathrm{mol} \mathrm{C}\right)$ to sulphate consuming 
$326\left(\Delta \mathrm{G}^{0}=-61 \mathrm{~kJ} / \mathrm{mol} \mathrm{C}\right)$ and thus did not necessarily require eutrophication (Schobben et al.,

327

328

329

330

331

332

333

334

335

336

337

338

339

340

341

342

343

344

345

346

347

2016).

\subsection{Enhanced nitrogen fixation, Mo limitation and a shift in nutrient- $N$ inventory}

The protracted anoxic conditions in the Early Triassic promoted nitrogen fixation. The $\delta^{15} \mathrm{~N}$ values of $\sim 0.5$ to $-1 \%$ at Jiarong and Xiakou suggest $\mathrm{N}_{2}$ fixation dominated equatorial oceans. A similar scenario is suggested for Cretaceous oceanic anoxic events when comparably low $\delta^{15} \mathrm{~N}$ values are associated with black shale deposition (Junium and Arthur, 2007), highlighting a key role of diazotrophs (nitrogen fixers) under anoxic conditions.

Biological nitrogen fixation is an enzyme-catalyzed $\mathrm{N}_{2}$ reduction, which has low energy yields $\left(\Delta \mathrm{G}^{0}=-157 \mathrm{~kJ} / \mathrm{mol} \mathrm{N}\right)$ and has to overcome a large kinetic barrier to break three $\mathrm{N}-\mathrm{N}$ bonds in the $\mathrm{N}_{2}$ molecule (Altabet, 2006). This can only be achieved by diazotrophs that are exclusively prokaryotes. Most diazotrophs are anaerobic bacteria or archaea except for diazotrophic cyanobacteria which have special cell walls that inhibit oxygen diffusion (Altabet, 2006). This is because the nitrogenase enzyme has a metal center consisting of either Mo-Fe, V-Fe or Fe-only complexes and its function is irreversibly inhibited by free oxygen (Berman-Frank et al., 2003). Thus, diazotrophs generally prefer anoxic environments, require $\mathrm{P}$ as a nutrient, and metal ions for synthesizing the nitrogenase enzyme. Phosphorus availability may not have been a limiting factor in the Early Triassic ocean because of 1) increased terrestrial P input via enhanced weathering; 2) recycling of $P$ from anoxic sediments; and 3) reduced metazoan uptake following extinctions of shelly fossils that incorporated $\mathrm{P}$ in $\mathrm{CaCO}_{3}$ shells and biogenic apatite. This inference is supported by data from Jiarong, where $\mathrm{P}$ and $\mathrm{Al}$ contents are positively correlated $(\mathrm{r}=0.77, p<0.05)$ 
but not as significantly as Fe vs. $\mathrm{Al}(\mathrm{r}=0.96, p<0.05)$ and $\mathrm{V}$ vs. $\mathrm{Al}(\mathrm{r}=0.95, p<0.05)$ (Fig. 6), suggesting P sources were not entirely terrestrial.

Metabolizable trace metals Mo(VI), V(V) and Fe(II) are redox-sensitive and they can be scavenged from the water column into sediments under intensely anoxic and euxinic conditions. A scarcity of such trace nutrients could severely suppress nitrogen fixation, leading to a pause in nitrogen cycling after nitrate depletion and a consequent collapse in oceanic productivity (Fig. 1, model C). However, such a scenario seemingly did not occur, at least not globally or for the long term, in the Early Triassic. This is probably because Fe(II) availability was sufficiently high, being reduced from Fe oxides from riverine input and aeolian dust or directly derived from hydrothermal activity at mid-ocean ridges. High Fe(II) availability is consistent with the development of ferruginous conditions (Clarkson et al., 2016) and the global abundance of pyrite framboids in Early Triassic sediments (Wignall and Twitchett, 2002).

In contrast, the Mo reservoir was probably much smaller than the Fe reservoir with minor input into large sinks, and could be depleted more easily. However, Mo availability cannot be easily evaluated because Mo tends to sink in sediments under anoxic-euxinic conditions. Thus Mo concentration measured from sedimentary rocks mainly reflects water column redox changes and does not necessarily mirror Mo availability in seawater. A proper estimation would require multiple speculations on Mo input and sink. Mo limitation in this case is inferred from indirect evidence from $\delta^{15} \mathrm{~N}$. Mo-Fe nitrogenase is much more efficient than V-Fe and Fe-only nitrogenase (Berman-Frank et al., 2003). A shift in nitrogenase type leads to a change in the isotopic fractionation during nitrogen fixation $\left({ }^{14} \mathrm{~N}\right.$ is preferably used) which could have resulted in more negative values in sedimentary $\delta^{15} \mathrm{~N}$ (Zhang et al., 
2014). The sporadic development of more negative $\delta^{15} \mathrm{~N}$ values $(<-2 \% 0)$ in the Jiarong section might have been a manifestation of short pulses of Mo limitation. Alternatively, (or collectively), these low $\delta^{15} \mathrm{~N}$ values may also be explained by partial $\mathrm{NH}_{4}{ }^{+}$uptake. Low $\delta^{15} \mathrm{~N}$ values are comparably rare throughout Earth's history, including the Precambrian, where Mo was likely much less abundant than at any time in the Phanerozoic (Stüeken et al., 2016). However, $\delta^{15} \mathrm{~N}$ values $<-2 \%$ are seen during intensive anoxia, such as during the oceanic anoxic events in the early Jurassic and middle Cretaceous (Jenkyns et al., 2001; Junium and Arthur, 2007), suggesting Mo limitation and/or $\mathrm{NH}_{4}^{+}$-rich conditions may have occurred more frequently than previously thought.

Nitrate (including nitrite) and ammonium (including ammonia) are two end members of oceanic nutrient-N (Fig. 1). In oxic waters, nitrification actively converts $\mathrm{NH}_{4}{ }^{+}$ to $\mathrm{NO}_{3}$. Many primary producers rely on the nitrate supply from deep waters, brought up by mixing and upwelling (Fig. 2C). In contrast, in anoxic oceans, anammox, denitrification and dissimilatory nitrate reduction to ammonium (DNRA) compete for nitrate for high anaerobic energy yields (Fig.1; Table 1). Anammox consumes both $\mathrm{NH}_{4}{ }^{+}$and $\mathrm{NO}_{2}{ }^{-}$and produces nonnutritious $\mathrm{N}_{2}$. In the case of intense anoxia (e.g., fast expansion of OMZ) and especially euxinia, DNRA produces an electron sink and thus outcompetes denitrification for nitrate (An and Gardner, 2002; Giblin et al., 2013) (Table 1). Such conditions, typically accompanied by high temperatures, high organic carbon burial and sulphate reduction rates, are seen in polluted coastal environments today but were likely widespread in the Early Triassic oceans, especially during the P-T transition and in the late Smithian (Grasby et al., 2012; Sun et al., 2012; Schobben et al., 2015; Sun et al., 2015). Unlike denitrification and anammox, DNRA recycles nitrate to bioavailable $\mathrm{NH}_{4}{ }^{+}$. A combination of nitrate net consumption and 
enhanced nitrogen fixation and DNRA likely led to a shift from a $\mathrm{NO}_{3}-$ dominated nutrient-N inventory to one dominated by $\mathrm{NH}_{4}{ }^{+}$(Fig. 1, models B and C; Fig. 8). Though $\mathrm{NH}_{4}{ }^{+}$dominance does not necessarily result in $\mathrm{NH}_{4}{ }^{+}$accumulation to high concentrations. Once established, the only pathway to reverse this shift is through nitrification, which is a light-sensitive aerobic reaction (Zehr and Ward, 2002), thus requiring oxygenation of deeper (dark) waters.

\subsection{Comparison with the modern Black Sea and the heterogeneity of Early Triassic oceans}

The Black Sea is the world's largest anoxic basin and a contemporary analogue for an ammonium ocean that can be used to test our conceptual model. The $\mathrm{NH}_{4}{ }^{+}$concentration in the Black Sea is $\sim 0 \mu \mathrm{M}$ in oxygenated surface waters but increases significantly with depth and oxygen deficiency to $\sim 30 \mu \mathrm{M}$ at $250 \mathrm{~m}$ depth while nitrate concentration remains $\sim 0 \mu \mathrm{M}$ below the suboxic-anoxic interface (Fig. 7; Kuypers et al., 2003). Our model fits these observations - nitrate is depleted while ammonium accumulates in anoxic environments (Fig. 1 model B).

Accumulation of $\mathrm{NH}_{4}+$ in the Black Sea is at least partially due to strong stratification of the water column (Fig. 7). The freshwater discharge from the Danube and other rivers creates an oxic cap that prevents water column mixing. Though not a perfect analogue, the P-T oceans are also generally considered to be highly stratified due to extreme hothouse climate and stagnation of ocean circulations (e.g., Hotinski et al., 2001; Winguth et al., 2015).

In contrast to Black Sea surface waters, where nitrate still exists, low latitude shallowwater Early Triassic $\delta^{15} \mathrm{~N}$ values fall to $\sim 0 \%$ and lower immediately above the P-T boundary (Luo et al., 2011) and at the S-S transition, which suggests the nutrient-N supply to surface waters was composed entirely of newly fixed-N. This was probably due to intense photic zone euxina (Grice et al., 2005; Cao et al., 2009) which inhibited nitrification in the 
417 surface water. In contrast, $\delta^{15} \mathrm{~N}$ values from northern higher latitudes (e.g., Vindodden) have

418 a mixed signature of $\mathrm{N}$-fixation and nitrate. The presence of nitrate suggests nitrification was 419 still partially active in these settings at night, in the winter and/or in the oxygenated lower 420 euphotic zone.

421

422

423

424

425

426

427

428

429

430

431

432

433

434

435

436

437

438

439

\subsection{Ammonium fertilization}

Marine phytoplankton and newly generated organic matter have a near-constant stoichiometric composition ratio - C:N:P = 106:16:1, known as the Redfield ratio. The Redfield stoichiometry suggests a higher demand for nutrient-N than $\mathrm{P}$ amongst primary producers. At higher temperatures, eukaryotic phytoplankton have a reduced demand for $\mathrm{P}$ required for cellular protein synthesis and shifts the oceanic nutrient structure to one that is N-limited (Toseland et al., 2013). Diazotrophic cyanobacteria are uniquely suited to such environments due to their self-sufficiency in nutrient-N. The recycling of cyanobacterial biomass occurs rapidly during heterotrophy in the euphotic zone, releasing $\mathrm{NH}_{4}{ }^{+}$that can be assimilated by other phytoplankton (Fulton et al., 2012). Such processes could continue to the point that $\mathrm{P}$ is consumed in the euphotic zone and then becomes the limiting nutrient. Given this constraint and the lack of major shifts in the Redfield N/P ratio in the Early Triassic (Grasby et al., 2016), the size of the ancient deep ocean $\mathrm{NH}_{4}{ }^{+}$reservoir could not have been much greater than the modern ocean nitrate reservoir. This suggests an Early Triassic deep ocean $\mathrm{NH}_{4}{ }^{+}$concentration was unlikely to have been greater than $\sim 50 \mu \mathrm{M}$.

Phytoplankton (both eukaryotes and cyanobacteria) generally prefer $\mathrm{NH}_{4}^{+}$to $\mathrm{NO}_{3}^{-}$as a nutrient source, because of the redundant energy costs expended when reducing $\mathrm{NO}_{3}{ }^{-}$to $\mathrm{NH}_{4}{ }^{+}$(Zehr and Ward, 2002). The exception is diatoms which generally prefer $\mathrm{NO}_{3}{ }^{-}$as a nutrient-N source but they only appeared in the Jurassic. One contemporary example for 
$\mathrm{NH}_{4}{ }^{+}$fertilization is the long-lasting Texas Brown Tide at the Laguna Madre/Baffin Bay estuary, caused by the alga Aureomonas lagunensis. This species is able to use $\mathrm{NH}_{4}{ }^{+}$or $\mathrm{NO}_{2}{ }^{-}$ but not $\mathrm{NO}_{3}^{-}$and its enduring bloom was fertilized by $\mathrm{NH}_{4}{ }^{+}$produced by DNRA in an environment with high sulphide concentrations (An and Gardner, 2002). Similarly, regional primary productivity increase and stromatolite development (e.g., Pruss et al., 2006; Chen et al., 2014) in the Early Triassic were likely stimulated by $\mathrm{NH}_{4}{ }^{+}$fertilization. The extensive microbialite build-ups in the aftermath of end-Permian mass extinction (Fig. 2A, B) were probably constructed by diazotrophs $\left(\mathrm{NH}_{4}{ }^{+}\right.$self-sufficient by $\mathrm{N}$-fixation), or otherwise fertilized by ambient $\mathrm{NH}_{4}{ }^{+}$. The onset of microbialite development in the earliest Griesbachian clearly coincided with enhanced nitrogen fixation (Cao et al., 2009; Xie et al., 2010; Luo et al., 2011) - a feature also seen during the S-S transition. The bloom of prasinophyte algae immediately after the end-Permian mass extinction while $\mathrm{N}$-fixation by cyanobacteria was occurring, is suggested to have provided prasinophytes with $\mathrm{NH}_{4}^{+}$in nutrient-limited environments (Jia et al., 2012). The demise of microbialites towards the Middle Triassic (Fig. 2B) was likely due to a general amelioration of environmental stresses and the re-establishment of potent nitrification, reducing $\mathrm{NH}_{4}{ }^{+}$during deep-water reoxygenation (Fig. 1, model A).

\subsection{Ammonium intoxication}

Although it fertilizes phytoplankton, $\mathrm{NH}_{4}{ }^{+}$is a major metabolic waste and can be lethal to both animals and higher plants at high concentrations (Britto and Kronzucker, 2002). $\mathrm{NH}_{4}{ }^{+}$accumulation, for instance, is a widespread problem in modern fish farming. Terrestrial animals and birds convert $\mathrm{NH}_{4}{ }^{+}$to the much less toxic urea but aquatic animals generally rely on direct excretion of $\mathrm{NH}_{4}{ }^{+}$to ambient water (Ip et al., 2001). The lethal 
concentration of ammonium for a wide range of marine vertebrates is $12.5 \mu \mathrm{M}$ (Knoph and Thorud, 1996; U.S. Environmental Protection Agency, 1998), much lower than the $\sim 50 \mu \mathrm{M}$ maximum estimated for the Early Triassic oceans. In general, invertebrates are more tolerant to ammonia (i.e., total ammonia $=\mathrm{NH}_{4}{ }^{+}$and $\mathrm{NH}_{3}$ ) than vertebrates while freshwater animals are more tolerant than marine animals. The toxicity of total ammonia manifests as damage to the central nervous system in vertebrates and is amplified at higher pH (e.g., in seawater). This is because $\mathrm{NH}_{4}{ }^{+}$is more toxic but less diffusive while most animal membranes are more permeable to $\mathrm{NH}_{3}$ (Ip et al., 2001). Remineralization of organic $\mathrm{N}$ in anoxic environments exclusively leads to $\mathrm{NH}_{4}{ }^{+}$and $\mathrm{NH}_{3}$ accumulation (Fig. 1, models B and C). Since protein decay is independent of redox conditions, and nitrification is inhibited in anoxic waters, degradation of organic remains and diazotrophs could have, at least in short term, produced excessive $\mathrm{NH}_{4}{ }^{+}$that may, at least in part, explain the hitherto enigmatic Early Triassic extinction/changeover events amongst nekton such as conodonts and fish. Such groups would be somewhat immune to the typical end-Permian scenario of high temperatures and low oxygen levels due to their ability to migrate to higher latitudes and their upper water column habitats. Neither factor would help nekton escape $\mathrm{NH}_{4}{ }^{+}-\mathrm{NH}_{3}$ poisoning. Even at modest increases in concentrations, the swimming ability of animals such as fish is impaired (Ip et al., 2001).

On the other hand, cephalopods are exclusively carnivores with fast growth rates for most of their life cycle. They have a high demand for proteins and the dominance of amino acid metabolism leads to a high $\mathrm{NH}_{4}{ }^{+}$accumulation in their systems (Lee, 1995). Some groups of cephalopods have much high tolerance of $\mathrm{NH}_{4}{ }^{+}$because they retain this metabolic waste in their tissues to achieve neutral buoyancy while other groups did not develop this 
physiological mechanism, but instead transform toxic $\mathrm{NH}_{4}{ }^{+}$to $\mathrm{N}_{2}$ gas (e.g., Nautilus) or develop jelly-like chloride compounds to maintain buoyancy (Voight et al. 1995). Thus, the fast turnover of ammonoids during the end-Permian mass extinction may reflect the success of those groups with a tolerance for high $\mathrm{NH}_{4}{ }^{+}$concentrations. $\mathrm{NH}_{4}+$ levels in ammonoid soft tissue were probably often high and the post mortem release during burial maintains high ambient pH levels thus inhibiting calcium phosphate replacement (Clements et al., 2017). This likely explains why ammonoid soft body tissue is rarely seen in fossil Lagerstätte.

Ammonium concentrations are not recorded in sedimentary rocks. Quantitative Earth system modelling studies are needed to better constrain the concentration of total ammonia in the P-T oceans and to further validate this hypothesis. If correct, ammonium poisoning is a previously unidentified end-Permian and Early Triassic killing mechanism (Fig. 8) and, once accumulated, its removal from seawater is difficult under anoxic and stratified oceanic conditions.

\subsection{Loss of dissolved nutrient- $N$ in anoxic waters}

Since nitrification can occur at low oxygen concentrations, establishment of ammonium oceans in the Phanerozoic could only occur in highly stratified oceans and during intensive ocean anoxic events. In cases of moderately anoxic conditions or fast oscillations in (dys)oxic and anoxic conditions, ammonium is likely converted to nitrate, which would then be denitrified. Additionally, as observed in OMZs in contemporary Omani Shelf, offshore Peru and elsewhere, DNRA and anammox bacteria can form DNRA-Anammox coupling and account for nutrient-N losses in areas of no detectable denitrification (Jensen et al., 2011). These processes could result in losses of both ammonium and nitrate, leading to a decrease in dissolved inorganic nutrient-N inventory (Fig. 8). 


\section{Conclusion} universally high or universally low are both untenable. The transition from nitrate oceans to ammonium oceans was accompanied by decreases in both the respiration efficiency of organisms and in the oceanic nutrient-N reservoir (Fig. 8). Though controlled by regional 515 redox and oceanographic setting, $\mathrm{NH}_{4}{ }^{+}$could temporarily and regionally boost primary productivity although it was probably low in general since most nutrient-N was likely lost during persistent periods of anoxia. Enhanced sulphate reduction, which is widely implied in the P-T oceans, could be attributed to a functional shift in microbial communities from nitrate consumption to sulphate consumption in a nitrate-starved ocean and thus does not necessarily require eutrophication. which, in turn, is likely a synergetic effect of widespread ocean anoxia and intensive water column stratification. Though remaining conceptual and awaiting Earth system modelling studies to further constrain, ammonia toxicity has not been considered in geological studies, and yet it may have played a substantial role in suppressing complex life before the rise of oxygen and probably in selectivity during many past extinctions.

Acknowledgments: This is a contribution to DFG (German Science Foundation) Research Unit TERSANE (FOR 2332: Temperature-related stressors as a unifying principle in ancient extinctions; Project Jo 219/15). National Natural Science Foundation of China (41821001, 531 41602026, 41602016), the National Key R\&D Program of China (2016YFA0601104), and 
Natural Environment Research Council of UK (RG.EVEA.109961; NE/J01799X/1) financially supported this study. Editor T. Mather is thanked for professional handling. Constructive comments from E. Stüeken and two anonymous reviewers improved this paper. K. De Baets and C. Scotese are thanked for fruitful discussions.

\section{References}

Algeo, T.J., Chen, Z.Q., Fraiser, M.L., Twitchett, R.J., 2011. Terrestrial-marine teleconnections in the collapse and rebuilding of Early Triassic marine ecosystems. Palaeogeogr. Palaeoclimatol. Palaeoecol. 308, 1-11.

Altabet, M.A., 2006. Isotopic tracers of the marine nitrogen cycle: Present and past, in: Volkman, J.K. (Ed.), Marine Organic Matter: Biomarkers, Isotopes and DNA. Springer Berlin Heidelberg, Berlin, Heidelberg, pp. 251-293.

Altabet, M.A., 2007. Constraints on oceanic N balance/imbalance from sedimentary ${ }^{15} \mathrm{~N}$ records. Biogeosciences 4, 75-86.

An, S., Gardner, W.S., 2002. Dissimilatory nitrate reduction to ammonium (DNRA) as a nitrogen link, versus denitrification as a sink in a shallow estuary (Laguna Madre/Baffin Bay, Texas). Marine Ecology Progress Series 237, 41-50.

Berman-Frank, I., Lundgren, P., Falkowski, P., 2003. Nitrogen fixation and photosynthetic oxygen evolution in cyanobacteria. Research in Microbiology 154, 157-164.

Bottjer, D.J., Clapham, M.E., Fraiser, M.L., Powers, C.M., 2008. Understanding mechanisms for the endPermian mass extinction and the protracted Early Triassic aftermath and recovery. GSA Today 18, 4-10.

Bristow, L.A., Dalsgaard, T., Tiano, L., Mills, D.B., Bertagnolli, A.D., Wright, J.J., Hallam, S.J., Ulloa, O., Canfield, D.E., Revsbech, N.P., Thamdrup, B., 2016. Ammonium and nitrite oxidation at nanomolar oxygen concentrations in oxygen minimum zone waters. Proc Natl Acad Sci U S A 113, 10601-10606.

Britto, D.T., Kronzucker, H.J., 2002. $\mathrm{NH}_{4}{ }^{+}$toxicity in higher plants: a critical review. Journal of Plant Physiology 159, 567-584.

Cao, C., Love, G.D., Hays, L.E., Wang, W., Shen, S., Summons, R.E., 2009. Biogeochemical evidence for euxinic oceans and ecological disturbance presaging the end-Permian mass extinction event. Earth Planet. Sci. Lett. 281, 188-201.

Chen, Y., Jiang, H., Lai, X., Yan, C., Richoz, S., Liu, X., Wang, L., 2015. Early Triassic conodonts of Jiarong, Nanpanjiang Basin, southern Guizhou Province, South China. J. Asian Earth Sci. 105, 104121.

Chen, Z.-Q., Wang, Y., Kershaw, S., Luo, M., Yang, H., Zhao, L., Feng, Y., Chen, J., Yang, L., Zhang, L., 2014. Early Triassic stromatolites in a siliciclastic nearshore setting in northern Perth Basin, Western Australia: Geobiologic features and implications for post-extinction microbial proliferation. Global Planet. Change 121, 89-100. 
Clarkson, M.O., Wood, R.A., Poulton, S.W., Richoz, S., Newton, R.J., Kasemann, S.A., Bowyer, F., Krystyn, L., 2016. Dynamic anoxic ferruginous conditions during the end-Permian mass extinction and recovery. Nature Communications 7, 12236.

Clements, T., Colleary, C., De Baets, K., Vinther, J., 2017. Buoyancy mechanisms limit preservation of coleoid cephalopod soft tissues in Mesozoic Lagerstätten. Palaeontology 60, 1-14.

Elrick, M., Polyak, V., Algeo, T.J., Romaniello, S., Asmerom, Y., Herrmann, A.D., Anbar, A.D., Zhao, L., Chen, Z.-Q., 2017. Global-ocean redox variation during the middle-late Permian through Early Triassic based on uranium isotope and Th/U trends of marine carbonates. Geology 45, 163-166.

Feely, R.A., Trefry, J.H., Massoth, G.J., Metz, S., 1991. A comparison of the scavenging of phosphorus and arsenic from seawater by hydrothermal iron oxyhydroxides in the Atlantic and Pacific Oceans. Deep Sea Research Part A. Oceanographic Research Papers 38, 617-623.

Fulton, J.M., Arthur, M.A., Freeman, K.H., 2012. Black Sea nitrogen cycling and the preservation of phytoplankton $\delta^{15} \mathrm{~N}$ signals during the Holocene. Global Biogeochem. Cycles 26, GB2030.

Giblin, A., Tobias, C., Song, B., Weston, N., Banta, G., Rivera-Monroy, V., 2013. The importance of dissimilatory nitrate reduction to ammonium (DNRA) in the nitrogen cycle of coastal ecosystems. Oceanography 26, 124-131.

Grasby, S.E., Beauchamp, B., Embry, A., Sanei, H., 2012. Recurrent Early Triassic ocean anoxia. Geology 41, 175-178.

Grasby, S.E., Beauchamp, B., Knies, J., 2016. Early Triassic productivity crises delayed recovery from world's worst mass extinction. Geology 44, 779-782.

Grice, K., Cao, C., Love, G.D., Böttcher, M.E., Twitchett, R.J., Grosjean, E., Summons, R.E., Turgeon, S.C., Dunning, W., Jin, Y., 2005. Photic zone euxinia during the Permian-Triassic superanoxic event. Science 307, 706-709.

Guerrero, M.A., Jones, R.D., 1996. Photoinhibition of marine nitrifying bacteria. I. Wavelengthdependent response. Marine Ecology Progress Series 141, 183-192.

Hotinski, R.M., Bice, K.L., Kump, L.R., Najjar, R.G., Arthur, M.A., 2001. Ocean stagnation and endPermian anoxia. Geology 29, 7-10.

Hounslow, M.W., Hu, M., Mørk, A., Weitschat, W., Vigran, J.O., Karloukovski, V., Orchard, M.J., 2008. Intercalibration of Boreal and Tethyan time scales: the magnetobiostratigraphy of the Middle Triassic and the latest Early Triassic from Spitsbergen, Arctic Norway. Polar Research 27, 469-490.

Hulth, S., Aller, R.C., Gilbert, F., 1999. Coupled anoxic nitrification/manganese reduction in marine sediments. Geochim. Cosmochim. Acta 63, 49-66.

Ip, Y.K., Chew, S.F., Randall, D.J., 2001. Ammonia toxicity, tolerance, and excretion. Fish Physiology 20, 109-148.

Jenkyns, H.C., Gröcke, D.R., Hesselbo, S.P., 2001. Nitrogen isotope evidence for water mass denitrification during the Early Toarcian (Jurassic) oceanic anoxic event. Paleoceanography 16, 593-603.

Jensen, M.M., Lam, P., Revsbech, N.P., Nagel, B., Gaye, B., Jetten, M.S.M., Kuypers, M.M.M., 2011. Intensive nitrogen loss over the Omani Shelf due to anammox coupled with dissimilatory nitrite reduction to ammonium. The Isme Journal 5, 1660. 
Jia, C., Huang, J., Kershaw, S., Luo, G., Farabegoli, E., Perri, M.C., Chen, L., Bai, X., Xie, S., 2012. Microbial response to limited nutrients in shallow water immediately after the end-Permian mass extinction. Geobiology 10, 60-71.

Junium, C.K., Arthur, M.A., 2007. Nitrogen cycling during the Cretaceous, Cenomanian-Turonian Oceanic Anoxic Event II. Geochemistry Geophysics Geosystems 8, Q03002.

Kidder, D.L., Worsley, T.R., 2010. Phanerozoic Large Igneous Provinces (LIPs), HEATT (Haline Euxinic Acidic Thermal Transgression) episodes, and mass extinctions. Palaeogeogr. Palaeoclimatol. Palaeoecol. 295, 162-191.

Knies, J., Grasby, S.E., Beauchamp, B., Schubert, C.J., 2013. Water mass denitrification during the latest Permian extinction in the Sverdrup Basin, Arctic Canada. Geology 41, 167-170.

Knoph, M.B., Thorud, K., 1996. Toxicity of ammonia to Atlantic salmon (Salmo salar L.) in seawaterEffects on plasma osmolality, ion, ammonia, urea and glucose levels and hematologic parameters. Comparative Biochemistry and Physiology Part A: Physiology 113, 375-381.

Konovalov, S.K., Murray, J.W., Luther III, G.W., 2005. Basic processes of Black Sea biogeochemistry. Oceanology 18, 24-35.

Kump, L.R., Pavlov, A., Arthur, M.A., 2005. Massive release of hydrogen sulfide to the surface ocean and atmosphere during intervals of oceanic anoxia. Geology 33, 397-400.

Kuypers, M.M.M., Sliekers, A.O., Lavik, G., Schmid, M., Jørgensen, B.B., Kuenen, J.G., Sinninghe Damsté, J.S., Strous, M., Jetten, M.S.M., 2003. Anaerobic ammonium oxidation by anammox bacteria in the Black Sea. Nature 422, 608.

Lam, P., Jensen, M.M., Lavik, G., McGinnis, D.F., Müller, B., Schubert, C.J., Amann, R., Thamdrup, B., Kuypers, M.M.M., 2007. Linking crenarchaeal and bacterial nitrification to anammox in the Black Sea. Proceedings of the National Academy of Sciences 104, 7104-7109.

Lee, P.G., 1995. Nutrition of cephalopods: Fueling the system. Marine and Freshwater Behaviour and Physiology 25, 35-51.

Lehrmann, D.J., Payne, J.L., Felix, S.V., Dillett, P.M., Wang, H., Yu, Y.Y., Wei, J.Y., 2003. Permian-Triassic Boundary Sections from Shallow-Marine Carbonate Platforms of the Nanpanjiang Basin, South China: Implications for Oceanic Conditions Associated with the End-Permian Extinction and Its Aftermath. Palaios 18, 138-152.

Looy, C.V., Brugman, W.A., Dilcher, D.L., Visscher, H., 1999. The delayed resurgence of equatorial forests after the Permian-Triassic ecologic crisis. Proc. Natl. Acad. Sci. U.S.A. 96, 1385713862.

Luo, G.M., Wang, Y.B., Algeo, T.J., Kump, L.R., Bai, X., Yang, H., Yao, L., Xie, S.C., 2011. Enhanced nitrogen fixation in the immediate aftermath of the latest Permian marine mass extinction. Geology 39, 647-650.

McCready, R.G.L., Gould, W.D., Barendregt, R.W., 1983. Nitrogen isotope fractionation during the reduction of $\mathrm{NO}_{3}-$ to $\mathrm{NH}_{4}{ }^{+}$by Desulfovibrio sp. Canadian Journal of Microbiology 29, 231234.

Meyer, K.M., Kump, L.R., Ridgwell, A., 2008. Biogeochemical controls on photic-zone euxinia during the end-Permian mass extinction. Geology 36, 747-750.

Mørk, A., Elvebakk, G., Forsberg, A.W., Hounslow, M.W., Nakrem, h.A., Vigran, J.O., Weitschat, W., 1999. The type section of the Vikinghøgda Formation: a new Lower Triassic unit in central and eastern Spitsbergen. Polar Research 18, 51-82. 
Payne, J.L., Lehrmann, D.J., Wei, J.Y., Orchard, M.J., Schrag, D.P., Knoll, A.H., 2004. Large perturbations of the carbon cycle during recovery from the End-Permian extinction. Science 305, 506-509.

Penn, J.L., Deutsch, C., Payne, J.L., Sperling, E.A., 2018. Temperature-dependent hypoxia explains biogeography and severity of end-Permian marine mass extinction. Science 362, eaat1327.

Pruss, S.B., Bottjer, D.J., Corsetti, F.A., Baud, A., 2006. A global marine sedimentary response to the end-Permian mass extinction: Examples from southern Turkey and the western United States. Earth-Sci. Rev. 78, 193-206.

Quan, T.M., Falkowski, P.G., 2009. Redox control of N:P ratios in aquatic ecosystems. Geobiology 7, 124-139.

Rabalais, N.N., Turner, R.E., Wiseman, W.J., 2002. Gulf of Mexico Hypoxia, a.k.a. "The Dead Zone". Annual Review of Ecology and Systematics 33, 235-263.

Schobben, M., Stebbins, A., Ghaderi, A., Strauss, H., Korn, D., Korte, C., 2015. Flourishing ocean drives the end-Permian marine mass extinction. Proceedings of the National Academy of Sciences 112, 10298-10303.

Schobben, M., Stebbins, A., Ghaderi, A., Strauss, H., Korn, D., Korte, C., 2016. Eutrophication, microbialsulfate reduction and mass extinctions. Communicative \& Integrative Biology 9, e1115162.

Schoepfer, S.D., Henderson, C.M., Garrison, G.H., Ward, P.D., 2012. Cessation of a productive coastal upwelling system in the Panthalassic Ocean at the Permian-Triassic Boundary. Palaeogeogr. Palaeoclimatol. Palaeoecol. 313-314, 181-188.

Scotese, C.R., Moore, T.L., 2014. Atlas of Phanerozoic Ocean Currents and Salinity (Mollweide Projection), PALEOMAP Project PaleoAtlas for ArcGIS, PALEOMAP Project, Evanston, Illinois.

Sigman, D., Karsh, K., Casciotti, K., 2009. Ocean process tracers: nitrogen isotopes in the ocean, Encyclopedia of Ocean Science, 2nd edition. Elsevier, Amsterdam, pp. 4138-4153.

Smith, J.M., Chavez, F.P., Francis, C.A., 2014. Ammonium Uptake by Phytoplankton Regulates Nitrification in the Sunlit Ocean. PLoS ONE 9, e108173.

Song, H., Tong, J., Algeo, T.J., Song, H., Qiu, H., Zhu, Y., Tian, L., Bates, S., Lyons, T.W., Luo, G., Kump, L.R., 2014. Early Triassic seawater sulfate drawdown. Geochim. Cosmochim. Acta 128, 95-113.

Stüeken, E.E., Kipp, M.A., Koehler, M.C., Buick, R., 2016. The evolution of Earth's biogeochemical nitrogen cycle. Earth-Sci. Rev. 160, 220-239.

Sun, Y.D., Joachimski, M.M., Wignall, P.B., Yan, C.B., Chen, Y.L., Jiang, H.S., Wang, L.N., Lai, X.L., 2012. Lethally hot temperatures during the Early Triassic greenhouse. Science 338, 366-370.

Sun, Y.D., Wignall, P.B., Joachimski, M.M., Bond, D.P.G., Grasby, S.E., Sun, S., Yan, C.B., Wang, L.N., Chen, Y.L., Lai, X.L., 2015. High amplitude redox changes in the late Early Triassic of South China and the Smithian/Spathian extinction. Palaeogeogr. Palaeoclimatol. Palaeoecol. 427, 62-78.

Toseland, A., Daines, S.J., Clark, J.R., Kirkham, A., Strauss, J., Uhlig, C., Lenton, T.M., Valentin, K., Pearson, G.A., Moulton, V., Mock, T., 2013. The impact of temperature on marine phytoplankton resource allocation and metabolism. Nature Climte Change 3, 979-984.

Twitchett, R.J., 2007. The Lilliput effect in the aftermath of the end-Permian extinction event. Palaeogeogr. Palaeoclimatol. Palaeoecol. 252, 132-144.

U.S. Environmental Protection Agency, 1998. Addendum to "Ambient Water Quality Criteria for Ammonia--1984.", in: Service, N.T.I. (Ed.), Springfield, VA. 
Van Cappellen, P., Ingall, E.D., 1994. Benthic phosphorus regeneration, net primary production, and ocean anoxia: A model of the coupled marine biogeochemical cycles of carbon and phosphorus. Paleoceanography 9, 677-692.

Van Mooy, B.A.S., Keil, R.G., Devol, A.H., 2002. Impact of suboxia on sinking particulate organic carbon: Enhanced carbon flux and preferential degradation of amino acids via denitrification. Geochim. Cosmochim. Acta 66, 457-465.

Voight, J.R., Pörtner, H.O., O'Dor, R.K., 1995. A review of ammonia-mediated buoyancy in squids (cephalopoda: Teuthoidea). Marine and Freshwater Behaviour and Physiology 25, 193-203.

Wignall, P.B., Bond, D.P.G., Sun, Y., Grasby, S.E., Beauchamp, B., Joachimski, M.M., Blomeier, D.P.G., 2016. Ultra-shallow-marine anoxia in an Early Triassic shallow-marine clastic ramp (Spitsbergen) and the suppression of benthic radiation. Geol. Mag. 153, 316-331.

Wignall, P.B., Twitchett, R.J., 2002. Extent, duration, and nature of the Permian-Triassic superanoxic event. Geol. Soc. Am. Speci. Paper 356, 395-413.

Winguth, A.M.E., Shields, C.A., Winguth, C., 2015. Transition into a Hothouse World at the PermianTriassic boundary-A model study. Palaeogeogr. Palaeoclimatol. Palaeoecol. 440, 316-327.

Xie, S., Pancost, R.D., Wang, Y., Yang, H., Wignall, P.B., Luo, G., Jia, C., Chen, L., 2010. Cyanobacterial blooms tied to volcanism during the 5 m.y. Permo-Triassic biotic crisis. Geology 38, 447450.

Zehr, J.P., Ward, B.B., 2002. Nitrogen cycling in the ocean: new perspectives on processes and paradigms. Applied and Environmental Microbiology 68, 1015-1024.

Zhang, X., Sigman, D.M., Morel, F.M.M., Kraepiel, A.M.L., 2014. Nitrogen isotope fractionation by alternative nitrogenases and past ocean anoxia. Proc. Natl. Acad. Sci. U.S.A. 111, 4782-4787.

Zhao, L., Chen, Y., Chen, Z.-q., Cao, L., 2013. Uppermost Permian to Lower Triassic Conodont Zonation from Three Gorges Area, South China. Palaios 28, 523-540.

\section{Figure and table captions}

Fig. 1 The marine nitrogen cycle with sub-models for oxic (A), anoxic (B) and euxinic (C) conditions. Blue arrows are aerobic reactions; red arrows are anaerobic reactions; black arrows are reactions with aerobic and anaerobic pathways. Bold lines are favoured reactions, whereas dashed lines are possible, but unfavoured reactions. Lightning contributes $\sim 5-8 \%$ of total fixed nitrogen and is generally considered as a constant input in geological studies. Sub-models represent end-member situations and do not include the oxygen minimum zone in oxic oceans and oxygenated surface layers in anoxic and euxinic oceans. In model $\mathrm{B}$, nitrate is consumed by reactions 5, 6, 7 and 8 
while resupply of nitrate is inhibited because reaction 4 is a light-inhibited aerobic reaction. In the model $\mathrm{C}$, nitrogen fixation can be inhibited due to removal of metabolizable Mo, $\mathrm{V}$ and Fe in the water column, leading to suppression of the nitrogen cycle. Nutrient- $\mathrm{N}$ systematically becomes dominated by $\mathrm{NH}_{3} / \mathrm{NH}_{4}+$ in anoxic and euxinic conditions. Anammox = anaerobic ammonium oxidation, DNRA = dissimilatory nitrate reduction to ammonium.

Fig. 2 A., Early Triassic palaeogeography, ocean currents and sites of microbial buildups (Pruss et al., 2006; Chen et al., 2014; Scotese and Moore, 2014). B., Temporal occurrences of microbial buildups (geographic occurrences shown in A), redox conditions and equatorial seawater temperatures (Wignall and Twitchett, 2002; Grasby et al., 2012; Sun et al., 2012; Sun et al., 2015) in the Early Triassic. For redox conditions, the blue colour stands for a globally oxic condition; black stands for generally anoxic condition while white stands for regional oxic conditions in some basins. These redox histories derive from studies in Alps, British Columbia, Canadian Arctic, Japan, South China, Spitsbergen etc. C., Simplified models comparing nitrogen cycles between a well oxygenated nitrate ocean and an Early Triassic stratified ammonium ocean. Note that in anoxic oceans denitrification can occur in all water depths while nutrient-N uptake by phytoplankton can only occur in the euphotic zone.

Fig. 3 Cross plots of total nitrogen and total organic carbon content of decarbonatized sample residues. Intercepts on the TN axis indicate the presence of excess silicate-bound nitrogen in the samples.

Fig. 4 Geochemical records from three study sections, showing a gradual decrease in $\delta^{15} \mathrm{~N}$ in the Early Triassic, a negative shift in $\delta^{15} \mathrm{~N}$ towards the S-S boundary, the covariation of 
$\delta^{13} \mathrm{C}_{\text {carb }}$ and $\delta^{13} \mathrm{C}_{\text {org }}$ at Jiarong and a near antithetic relationship between $\delta^{15} \mathrm{~N}$ and C/Natomic. Redox conditions and biostratigraphy from the three sections, $\delta^{13} \mathrm{C}_{\text {carb }}$ from Jiarong and $\delta^{13} \mathrm{Corg}$ from Vindodden are from Zhao et al., (2013), Sun et al. (2015), Wignall et al. (2016) and Elrick et al. (2017). Redfield ratio (C/N=6.6) is used as a reference.

Fig. 5 Summary of published $\delta^{15} \mathrm{~N}$ records in the Late Permian to Early Triassic interval, showing strong denitrification occurred geographically in different settings across the P-T boundary. The onset and duration of the P-T water column denitrification shows regional variations, probably controlled by local redox conditions and palaeoceanographic settings.

Fig. 6 Cross plots of V vs. Al, Mo vs. Al, Fe vs. Al and P vs. Al from Jiarong, South China. The original dataset is fully accessible in Sun et al. (2015).

Fig. 7 Depth profile of $\mathrm{NO}_{3}^{-}, \mathrm{NH}_{4}^{+}, \mathrm{O}_{2}$ and $\mathrm{S}^{2-}$ concentrations in the highly stratified contemporary Black Sea, showing a depletion of $\mathrm{NO}_{3}-$ but accumulation of $\mathrm{NH}_{4}{ }^{+}$in anoxic water column (modified from Konovalov et al., 2005).

Fig. 8 The evolution of the ammonium ocean and changes in energy structures in the aftermath of the end-Permian mass extinction.

Table 1 Comparison of energy yields (standard Gibbs free energy) of aerobic and anaerobic respiration. Glucose $\left(\mathrm{C}_{6} \mathrm{H}_{12} \mathrm{O}_{6}\right)$ is the most important source of energy for cellular respiration and thus is used for calculation of comparable energy yields here. Isotopic enrichment $(\varepsilon)$ is only for nitrogen reactions and approximated by $\delta^{15} \mathrm{~N}_{\text {product- }}$ $\delta^{15} \mathrm{~N}_{\text {reactant }}$ (for $\varepsilon<1000 \%$ ) (McCready et al., 1983; Sigman et al., 2009; Zhang et al., 2014). Note that DNRA produces less energy than denitrification in term of per mol C; 
however, in intense anoxia where nitrate is a limited resource, DNRA yields more energy than denitrification in measure of per mole N.

779 Table 2 A comparision of $\delta^{15} \mathrm{~N}$ and $\mathrm{C} / \mathrm{N}_{\text {atomic }}$ ratio in clay-poor rocks and clay-rich rocks that 780 are closely spaced to each other, showing measured $\delta^{15} \mathrm{~N}$ and $\mathrm{C} / \mathrm{N}_{\text {atomic }}$ ratios are generally consistent in the two types of rock but $\mathrm{C} / \mathrm{N}_{\text {atomic }}$ ratios are more variable in Early Triassic (TOC poor) rocks.

Supplementary materials: Data file (including the original dataset and statistical analyses

784 on the data)

785 


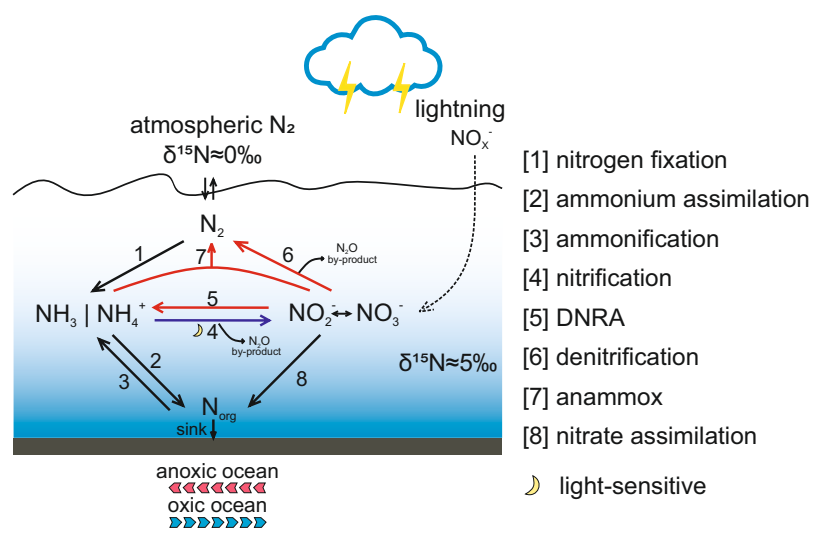

A fully oxygenated ocean

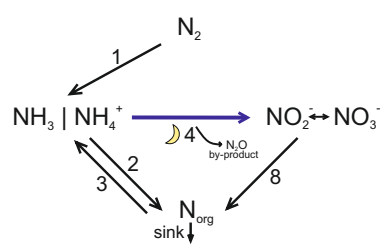

B anoxic ocean with replete Fe supply

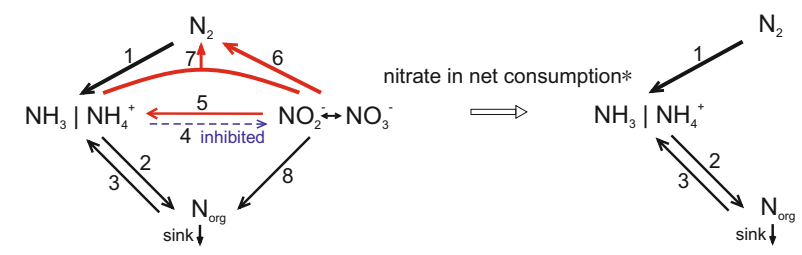

C fully euxinic ocean

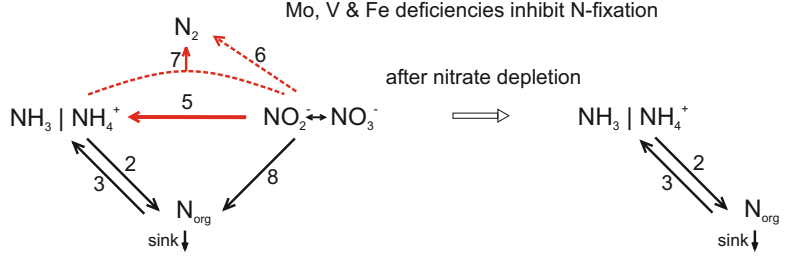

* --depends on the intensity of anoxia 

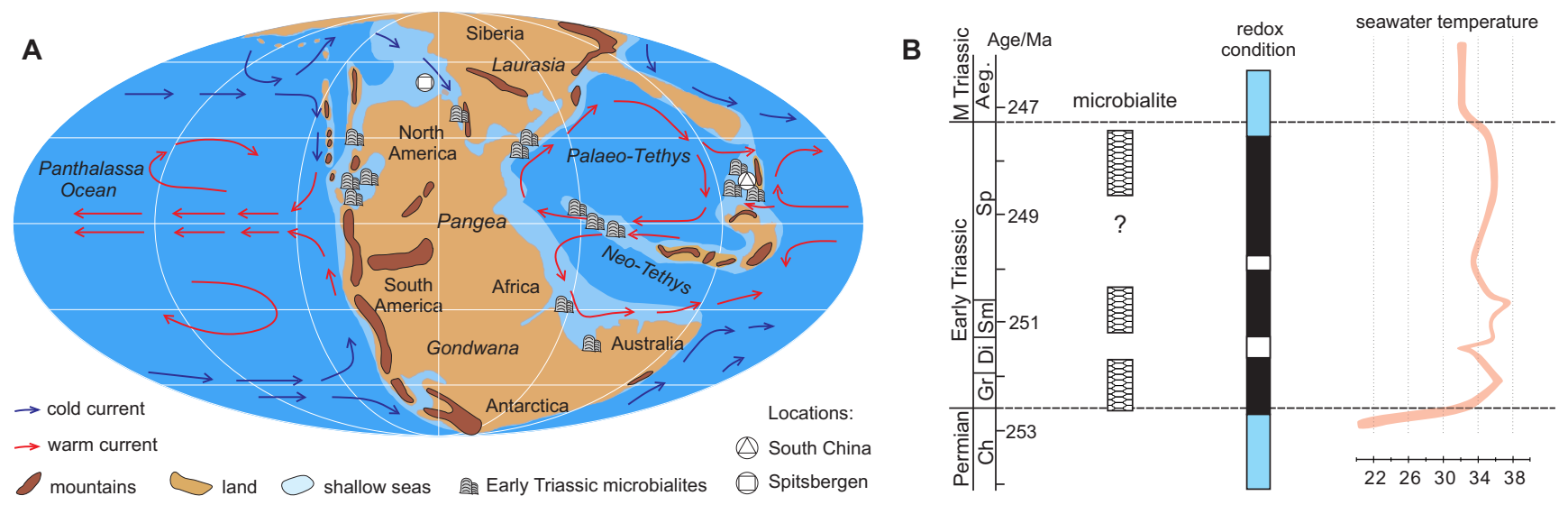

C

Well circulated and oxygenated ocean (nitrate ocean)

anoxic and stratified Early Triassic ocean (ammonium ocean)

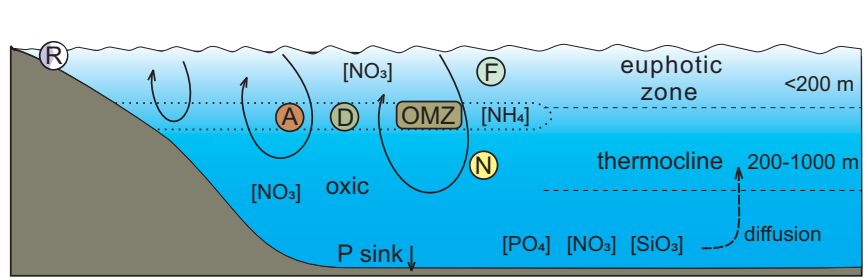

microbial buildup

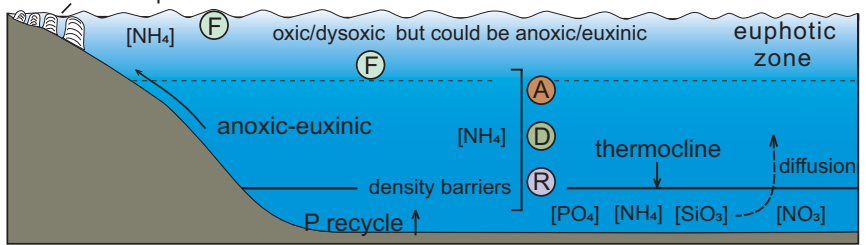

KEYS: OMZ oxygen minimum zone

(A) anammox (D) denitrification (F) nitrogen fixation

(N) nitrification

(R) DNRA 

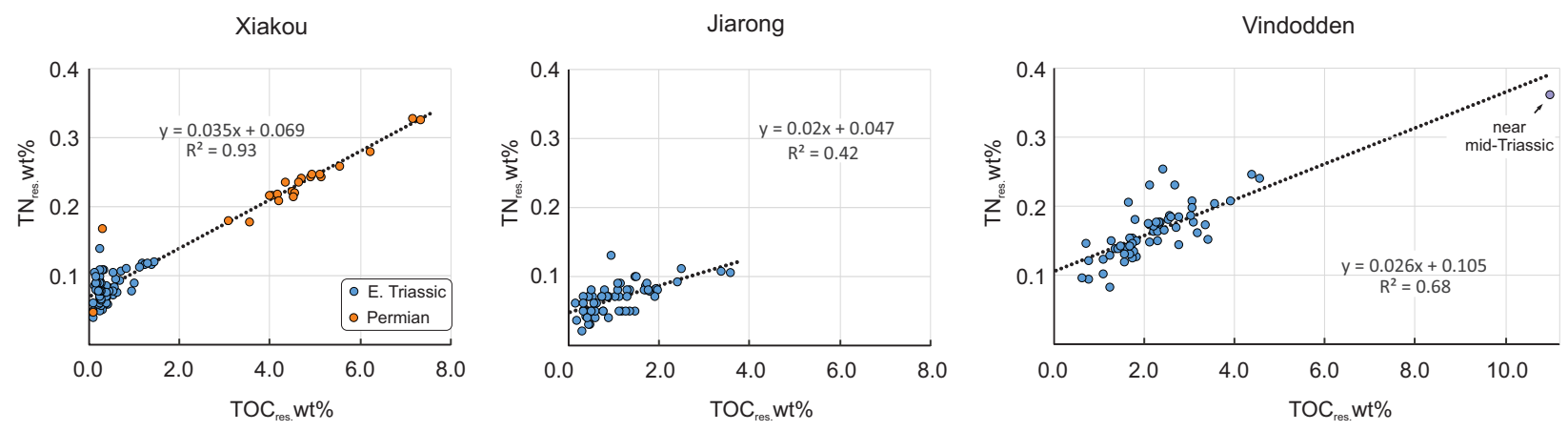


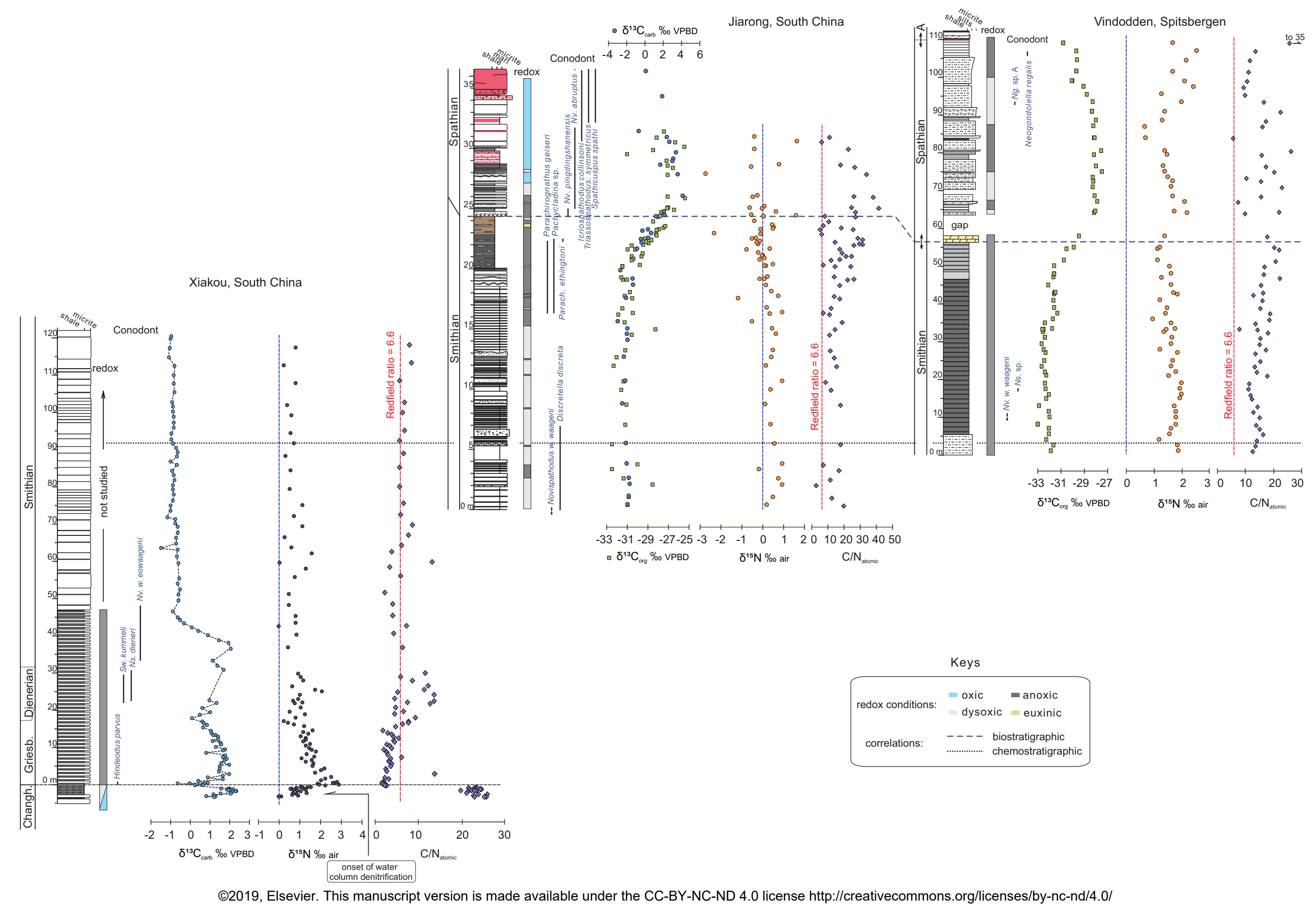




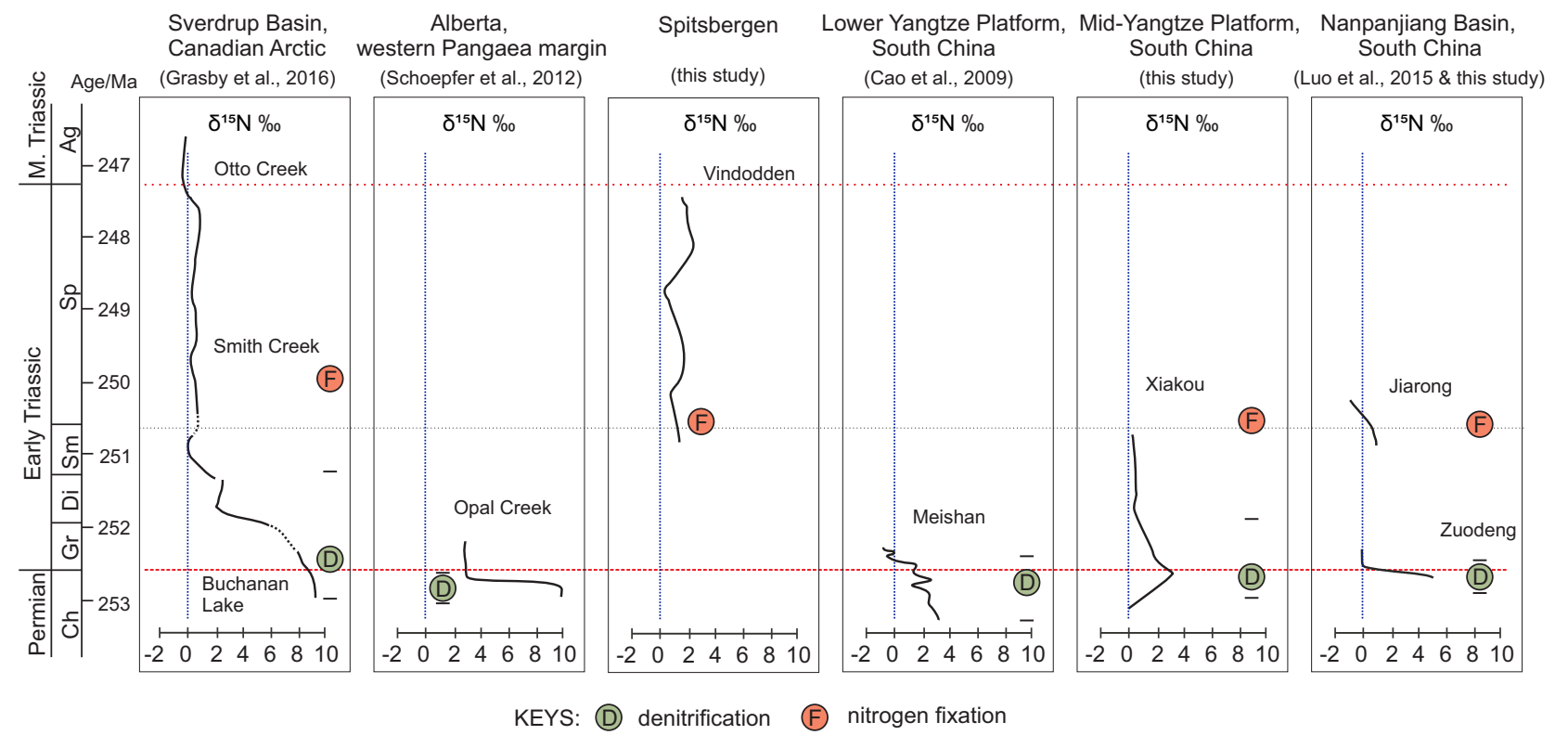



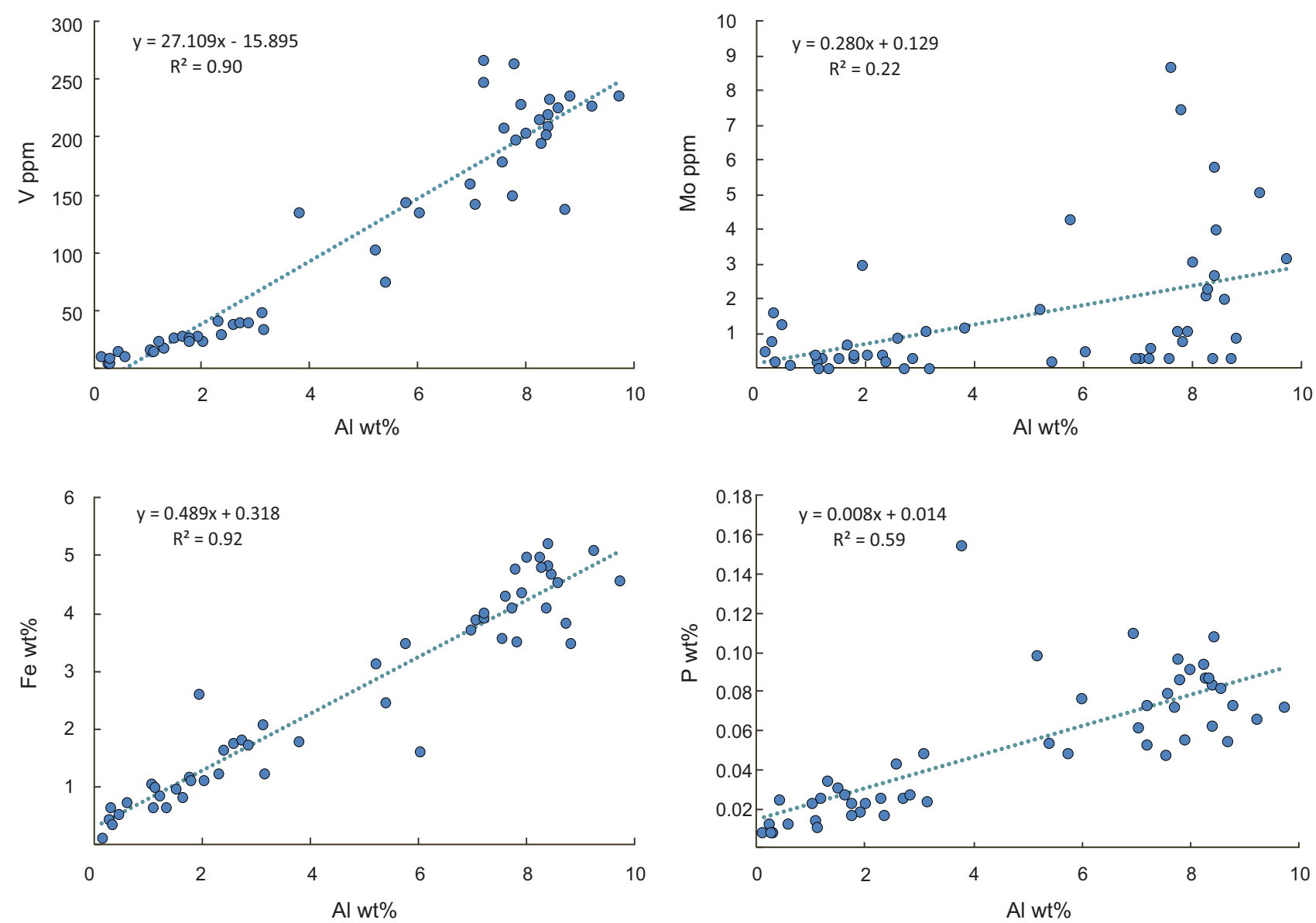


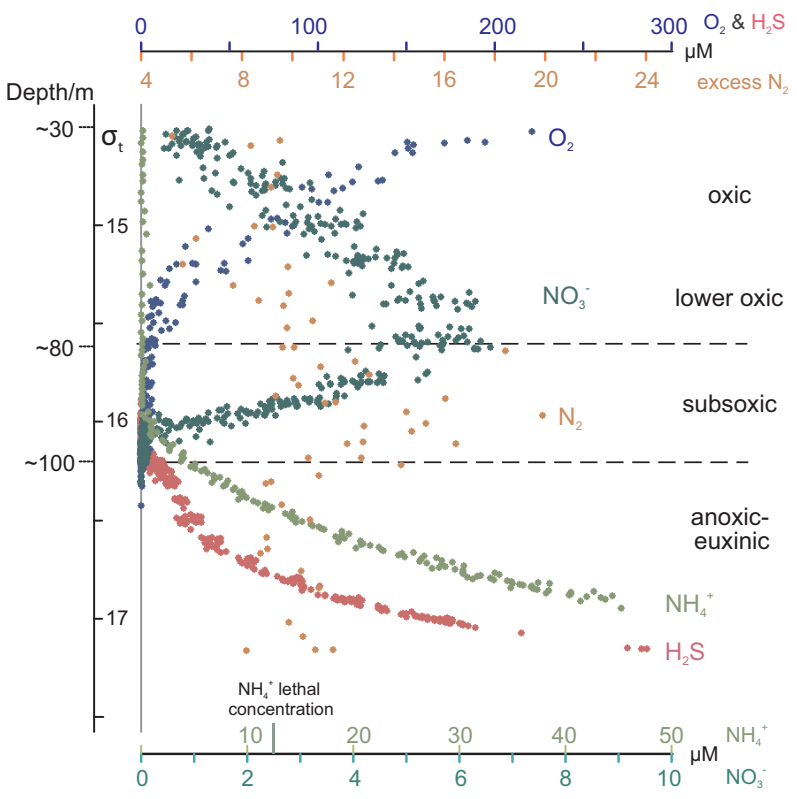




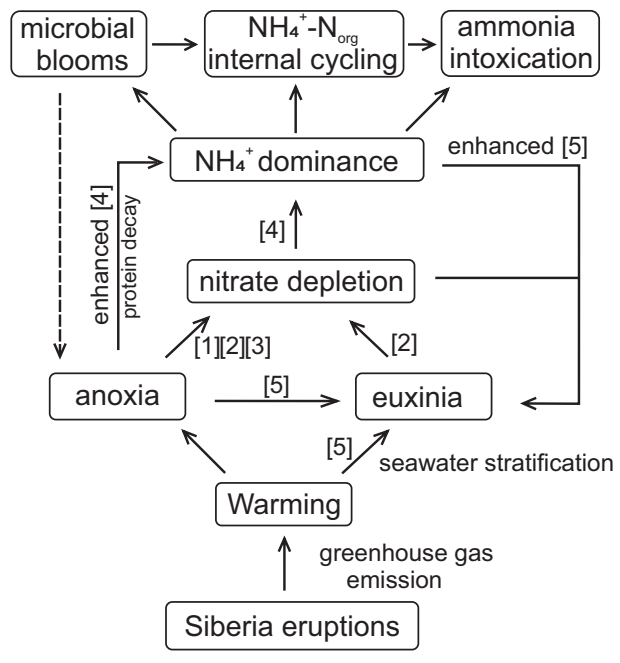

State

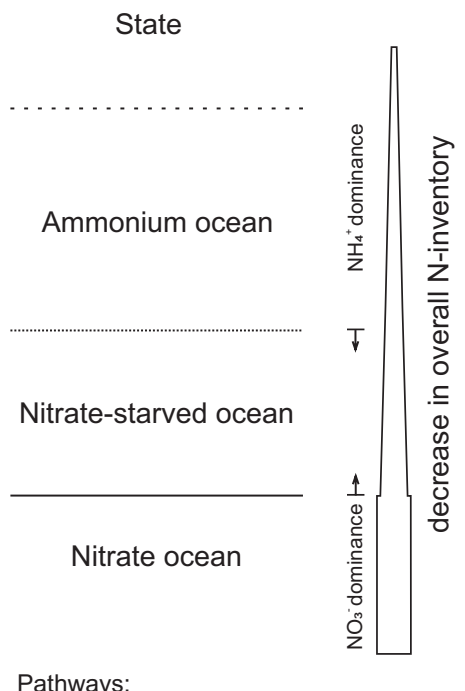

[1] denitrification
[2] DNRA
Energy structure

anaerobic respiration

$\Delta \mathrm{G}_{0}=-61 \mathrm{~kJ} / \mathrm{mol} \mathrm{C} \quad$ [5]

$\Delta \mathrm{G}_{0}=-157 \mathrm{~kJ} / \mathrm{mol} \mathrm{N}[4]$

$\Delta \mathrm{G}_{\mathrm{o}}=-157 \mathrm{~kJ} / \mathrm{mol} \mathrm{N}[4]$

$\Delta G_{0}=-179 \mathrm{~kJ} / \mathrm{mol} \mathrm{N}$ [3]

$\Delta \mathrm{G}_{\mathrm{o}}=-312 \mathrm{~kJ} / \mathrm{mol} \mathrm{C}$ [2]

$\Delta \mathrm{G}_{\mathrm{o}}=-445 \mathrm{~kJ} / \mathrm{mol} \mathrm{C}[1]$

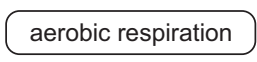

$\Delta \mathrm{G}_{0}=-478 \mathrm{~kJ} / \mathrm{mol} \mathrm{C}$

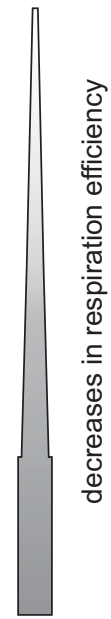

[3] anammox

[4] $\mathrm{N}_{2}$ fixation

[5] sulphate reduction 


\begin{tabular}{|c|c|c|c|c|c|}
\hline \multirow{2}{*}{$\begin{array}{c}\text { Energy extraction } \\
\text { pathway }\end{array}$} & \multirow{2}{*}{ Simplified reaction } & \multicolumn{3}{|c|}{ Energy yield $\left(\Delta G^{0}\right)$} & \multirow{2}{*}{$\begin{array}{c}\text { isotopic enrichment }(\varepsilon) \\
\% \circ \\
\end{array}$} \\
\hline & & $\mathrm{kJ} / \mathrm{mol} \mathrm{C}$ & $\mathrm{kJ} / \mathrm{mol} \mathrm{N}$ & $\mathrm{kJ} / \mathrm{mol} \mathrm{S}$ & \\
\hline aerobic respiration & $\mathrm{C}_{6} \mathrm{H}_{12} \mathrm{O}_{6}+6 \mathrm{O}_{2}=6 \mathrm{CO}_{2}+6 \mathrm{H}_{2} \mathrm{O}$ & -478 & -- & -- & \\
\hline denitrification & $5 \mathrm{C}_{6} \mathrm{H}_{12} \mathrm{O}_{6}+24 \mathrm{NO}_{3}^{-}+24 \mathrm{H}^{+}=30 \mathrm{CO}_{2}+12 \mathrm{~N}_{2}+42 \mathrm{H}_{2} \mathrm{O}$ & -445 & -556 & -- & $5-30$ \\
\hline DNRA & $\mathrm{C}_{6} \mathrm{H}_{12} \mathrm{O}_{6}+3 \mathrm{NO}_{3}^{-}+6 \mathrm{H}^{+}=6 \mathrm{CO}_{2}+3 \mathrm{NH}_{4}^{+}+3 \mathrm{H}_{2} \mathrm{O}$ & -312 & -623 & -- & $-5--30$ \\
\hline anammox & $\mathrm{NH}_{4}^{+}+\mathrm{NO}_{2}^{-}=\mathrm{N}_{2}+2 \mathrm{H}_{2} \mathrm{O}$ & -- & -179 & -- & $>10$ \\
\hline nitrogen fixation & $\mathrm{N}_{2}+10 \mathrm{H}^{+}+8 \mathrm{e}^{-}=2 \mathrm{NH}_{4}^{+}+\mathrm{H}_{2}$ & -- & -157 & -- & -1 to $2^{a}$ or to $-7^{b}$ \\
\hline sulphate reduction & $\mathrm{C}_{6} \mathrm{H}_{12} \mathrm{O}_{6}+3 \mathrm{SO}_{4}^{2-}=6 \mathrm{CO}_{2}+6 \mathrm{H}_{2} \mathrm{O}+3 \mathrm{~S}^{2-}$ & -61 & -- & -121 & \\
\hline ethanol fermentation & $\mathrm{C}_{6} \mathrm{H}_{12} \mathrm{O}_{6}=2 \mathrm{CO}_{2}+2 \mathrm{C}_{2} \mathrm{H}_{5} \mathrm{OH}$ & -38 & -- & -- & \\
\hline
\end{tabular}

a., reaction calatlyzed by Mo-Fe nitrogenase enzyme;

b., reaction calatlyzed by V-Fe or Fe-only nitrogenase enzyme. 
Sample No. Height/m Lithology

\begin{tabular}{|c|c|c|c|c|c|c|c|c|}
\hline \multicolumn{9}{|c|}{ Permian (high TOC) samples } \\
\hline XK 248B & -0.88 & limestone & 74.7 & 1.13 & 0.06 & -26.13 & 1.05 & 23.5 \\
\hline XK 248A & -0.81 & marl & 14.4 & 3.05 & 0.15 & -26.35 & 1.36 & 23.1 \\
\hline XK 247A & -0.90 & limestone & 73.2 & 1.21 & 0.06 & -26.11 & 1.53 & 23.8 \\
\hline XK 247B & -0.95 & marl & 29.3 & 2.86 & 0.15 & -26.13 & 1.10 & 21.8 \\
\hline \multicolumn{9}{|c|}{ Triassic (low TOC) samples } \\
\hline XK 22.1 & 22.1 & limestone & 92.5 & 0.03 & 0.01 & -28.74 & 1.13 & 7.5 \\
\hline XK 21.9 & 21.9 & black shale & 19.3 & 1.05 & 0.10 & -28.57 & 0.76 & 12.7 \\
\hline
\end{tabular}

